Aus der Abteilung Biochemie I

(Prof. Dr. rer. nat. B. Schwappach)

im Zentrum Biochemie und Molekulare Zellbiologie

der Medizinischen Fakultät der Universität Göttingen

\title{
Die Bedeutung der Hämoxygenase-1/ Kohlenmonoxid- und NO-Synthase/ Stickoxid-Signalsysteme für das Wachstum von primär kultivierten adulten Rattenhepatozyten
}

\author{
INAUGURAL-DISSERTATION \\ zur Erlangung des Doktorgrades für Zahnheilkunde \\ der Medizinischen Fakultät \\ der Georg-August-Universität zu Göttingen
}

\author{
vorgelegt von \\ Hasan Acil \\ aus \\ Kirikhan/Türkei
}

Göttingen 2011 
Dekan: Prof. Dr. med. C. Frömmel

I. Berichterstatterin: Prof. Dr. rer. nat. I. Probst

II. Berichterstatter/ in:

III. Berichterstatter/ in:

Tag der mündlichen Prüfung: 


\section{Inhaltsverzeichnis}

1 Einleitung 8

2 Material und Methoden 16

2.1 Tiere und Tierhaltung 16

2.2 Isolierung von Hepatozyten 16

2.2.1 Medien 16

2.2.2 Perfusion der Leber 17

2.2.3 Herstellung der Hepatozyten-Zellsuspension 18

2.2.4 Herstellung der Stromalzellen-Zellsuspension 18

2.3 Medien und Stammlösungen 19

2.4 Anheftung und Kultivierung von Hepatozyten 22

2.5 Herstellung von konditionierten Kulturmedien 22

2.5.1 Gewinnung von Stromalzell-konditioniertem Medium

(SZ-CM) 22

2.5.2 Gewinnung von Hepatozyten-konditioniertem Medium (HCM) 23

2.6 Kollagenherstellung 23

2.7 Quantitative Bestimmung des DNA-Gehaltes 24

2.8 Bestimmung der Menge an HO-1 und iNOS m-RNA durch quantitative realtime PCR 24

2.9 Bestimmung der NO-Synthase-Aktivität 29

2.10 Geräte $\quad 30$

2.11 Chemikalien 31

3 Ergebnisse 33

3.1 Einfluss von Lithiumchlorid auf die Zellteilung und die induzierbare NO-Synthase $\quad 33$

3.1.1. Steigerung der iNOS-Induktion durch Lithiumchlorid $\quad 33$

3.1.2. Steigerung der iNOS-Aktivität durch Lithiumchlorid $\quad 35$

3.1.3. Wachstumssteigerung durch Lithiumchlorid 36

3.1.4. Einfluss von NO-Synthase-Hemmstoffen auf das 
3.2 Einfluss des Furoxans CAS 1609 auf Zellteilung und iNOSInduktion

3.3 Induktion der Hämoxygenase-1 durch CAS 1609

3.4 Wirkung des CO-Donators Tricarbonylchlororuthenium(II)Dimer (CORM 2) auf das Hepatozytenwachstum

3.5 Aufbau einer Kultur proliferierender Hepatozyten aus der adulten Maus

4.1 Einfluss von NO auf die Leberregeneration in vivo

4.2 Einfluss von NO auf die Proliferation der Hepatozyten in vitro

4.3 Wirkung des „NO-Donators“ CAS 1609 auf die in-vitroProliferation von Hepatozyten

4.4 Direkte Beteiligung von Hämoxygenase-1 und Kohlenmonoxid an der Proliferations-Signalkette

4.5 Die Bedeutung der HO-1/CO und NOS/NO Signalsysteme für das Wachstum von Rattenhepatozyten in vitro

5 Zusammenfassung 


\section{Abkürzungen}

$1400 \mathrm{~W}$

AMP

Bcl-2

$\mathrm{B}_{2} \mathrm{MG}$

BNIP-3

BSA

CAS 1609

CO-HB

CoPP

CORM 2

COX 2

DFU

DNA

CDNA

EDTA

EGF

FAD

FCS

FGFb

FMN

GM

HCM

$\mathrm{HO}-1$

$\mathrm{H}_{2} \mathrm{O}_{2}$

HSP

IFNy

IL

KM

$\mathrm{LiCl}$

L-NAME

L-NIL
$\mathrm{N}$-(3-Aminomethyl)benzylacetamidin

Adenosinmonophosphat

B-cell lymphoma 2

$B_{2}$-Mikroglobulin

$\mathrm{BCL}$ 2/ adenovirus E1B $19 \mathrm{kDa}$ protein-interacting protein

Bovines Serumalbumin

4-Hydroxymethyl-Furoxan-3-Carboxamid

Carboxy-Hämoglobin

Kolbaltprotoporphyrin

Tricarbonylchlorruthenium (II) Dimer

Cyclooxygenase 2

5,5-Dimethyl-3-(3-Fluorophenyl)-4-(4-

Methylsulphonyl)phenyl-2(5H)-Furanon

Desoxyribonukleinsäure

complementary Desoxyribonukleinsäure

Ethylendiamintetraacetat

Epidermal growth factor

Flavinadenindinukleotid

Fetal calf serum

Fibroblast growth factor b

Flavinmononukleotid

Grundmedium

Hepatozyten-konditioniertes Medium

Hämoxygenase-1

Wasserstoffperoxid

Hitzeschockprotein

Interferon gamma

Interleukin

Komplettmedium

Lithiumchlorid

L-Nitroarginin-Methylester

L-N $\mathrm{N}^{6}-(1-$ Iminoethyl)lysine 
LPS

MAT

mRNA

NF-kB

NNP

PBGD

SAM

sGC

SZ-CM

TNFa

Upm
Lipopolysaccharid

Methioninadenosyltransferase

messenger Ribonukleinsäure

Nuclear factor kappa-light-chain-enhancer of activated Bcells

Natrium-Nitroprussid

Porphobilinogen Deaminase

S-Adenosylmethionin

Guanylat-Cyclase

Stromalzellen-konditioniertes Medium

Tumornekrosefaktor $\alpha$

Umdrehungen pro Minute 


\section{Abbildungs- und Tabellenverzeichnis}

Abb. 1: Zeitlicher Verlauf der iNOS- Induktion während des Hepatozytenwachstums.

Abb. 2: Die Entwicklung der NO-Synthase-Aktivität im Verlauf des Wachstums kultivierter Rattenhepatozyten.

Abb. 3: Einfluss von Lithiumchlorid und Interleukin-1B auf das Wachstum adulter Hepatozyten in Primärkultur.

Abb. 4: Einfluss von CAS 1609 und Lithiumchlorid auf das Wachstum adulter Hepatozyten.

Abb. 5: Hemmung der iNOS-Induktion durch CAS 1609.

Abb. 6: Zeitlicher Verlauf von Hepatozyten unter Einfluss von CAS 1609 in Primärkultur.

Abb. 7: Zeitlicher Verlauf der Hämoxygenase-1 mRNA-Expression.

Abb. 8: Mitogene Wirkung von CORM 2 auf das Wachstum der Rattenhepatozyten. Dosis-Wirkungskurve.

Abb. 9: Einfluss der Biomatrix (Plattenbeschichtung) und der

Medienzusammensetzung auf das Wachstum der Maus-Hepatozyten.

Abb. 10: Einfluss von Lithiumchlorid auf das Wachstum von adulten Maushepatozyten.

Abb. 11: Lichtmikroskopische Aufnahmen kultivierter Maushepatozyten. 51

Abb. 12: Hypothetische HGF-Signalkette, Beteiligung der eNOS an der Regulation.

Abb. 13: Die Regulation der NOS/NO und HO-1/CO Signalgeber und des Zellwachstums durch CAS 1609 und Enzymhemmstoffe.

Tab. 1: Einfluss von iNOS-spezifischen Hemmstoffen auf die NO-Synthase-Aktivität und das Wachstum von Hepatozyten.

Tab. 2: Vergleich der Kultursysteme zwischen Vázqez-Chantada et al. (2009), und dem in dieser Arbeit benutzten Kultursystem (Krause et al. 2010). 


\section{Einleitung}

\section{Die Bedeutung von Stickstoffmonoxid für das Hepatozytenwachstum}

Stickstoffmonoxid (NO, nitric oxide) spielt eine wichtige Rolle im menschlichen Körper, wie z.B. bei der Einstellung des Gefäßtonus, bei Signalübermittlung, Kreislaufregulation und Abwehr. In der Leber hat $\mathrm{NO}$ eine bedeutende regulatorische Rolle und beteiligt sich an der Modulation von hepatischen Enzymaktivitäten und kann diese direkt durch Interaktionen mit SH-Gruppen oder Häm hemmen (Obolenskaya et al. 1994, Clemens 1999). Die Wirkungsweise von NO ist stark von dessen Konzentration abhängig. Eine hohe Konzentration an NO führt zur DNA-Zerstörung und zur Apoptose der Zelle (Clemens 1999); eine niedrige Konzentration an NO beeinflusst die Durchblutung der Leber und hat antiinflammatorische, antithrombotische und hepatoprotektive Effekte. NO hat sowohl pro- als auch antioxidantische Wirkungen (Joshi et al. 1999, Fitzhugh und Keefer 2000) und weist aber auch Apoptose-induzierende sowie -inhibierende Eigenschaften auf (Kim PK et al. 2001). Im zirkulierenden Blutkreislauf hat NO eine Halbwertszeit von <1s (Kelm 1999). Nach dieser Zeit wird NO durch die spontane Oxidation in Nitrit und Nitrat umgewandelt (Farzaneh-Far und Moore 2001). Die Wirkungsweise von NO an der Leber ist sehr komplex und wird in der Literatur oft widersprüchlich beschrieben.

Die Isoformen der NO-Synthase

Die NO-Synthase (NOS) produziert $\mathrm{NO}$ aus L-Arginin unter $\mathrm{O}_{2}$-Reduktion. Sie besitzt eine homodimere Struktur und benötigt als Cofaktoren FAD, FMN, Calmodulin, Tetrahydrobiopterin und Häm. Es gibt im Gewebe drei verschiedene NOS-Isoformen: die neuronale (nNOS, Typ I), die induzierbare (iNOS, Typ II) und die endotheliale NO-Synthase (eNOS, Typ III). Nach Wei et al. (2002) wird nNOS in den Nervenzellen des Gehirns und in den Hepatozyten während der Leberzirrhose exprimiert (Wei et al. 2002). Esteban et al. (1997) wiesen die nNOS auch in immunopositiven Nervenendfasern, die sich in den Gefäßen der Leber befinden, nach. Die eNOS wird über die gesamten Hepatozyten der Leber, im Endothel von Leberarterien, 
Lebervenen, im Gallengangsepithel und den Sinusoiden gebildet (McNaughton et al. 2002). Nach Chen et al. (2003) hat sie eine wichtige Rolle bei der Aufrechterhaltung der Mikrozirkulation in der Leber. Die eNOS wird durch Calcium und Calmodulin reguliert (Wei et al. 2002) und konstitutiv exprimiert (Kim PK et al. 2004).

Die iNOS wird von Hepatozyten, Makrophagen und glatten Muskelzellen exprimiert (Harbrecht und Billiar 1995). Zytokine und Endotoxine sind für die Expression der iNOS in menschlichen Hepatozyten verantwortlich, ganz besonders während leberschädigender Prozesse wie Cholestase, Hepatitis und Leberzirrhose (FarzanehFar und Moore 2001, Farghali et al. 2002 und Chen et al. 2003). Die Freisetzung von Tumornekrosefaktor- $\alpha$ (TNFa) und Interleukin 6 (IL-6) induziert die Transkription des iNOS-Genes (Rai et al. 1998). An kultivierten Rattenhepatozyten wird die Expression von iNOS-mRNA ebenso durch IL-1 $\beta$ stimuliert (Nüssler et al. 1993) und auch durch oxidativen Stress induziert (Duval et al. 1996). Bei unkontrollierter und gesteigerter NO-Bildung durch die iNOS wird die Leber stark geschädigt (Suzuki et al. 1995). Chen et al. zeigten 2003, dass gewebeschädigende Prozesse auf Reaktionen von NO mit Produkten aus oxidativen Stressreaktionen z.B. mit Superoxid-Anionen zu Peroxynitrit ( $\left.\mathrm{ONOO}^{-}\right)$zurückzuführen sind, welche zu DNA-Schädigung und Phospholipid- und Tyrosinoxidation führen. Dabei ist die Wirkungsweise des durch die iNOS freigesetzten NO abhängig von dem Reduktionsstatus der Zelle. Die Zellen werden im Zustand der Ischämie von NO geschädigt, z.B. nach Transplantation (Isobe et al. 1999), bei Alkohol-Hepatitis (Zima et al. 2001) und medikamenteninduzierter Leberzellnekrose (Laskin et al. 1986).

\section{Die Bedeutung von NO bei der Leberregeneration}

Die Leberregeneration ist ein gut untersuchtes und beschriebenes Forschungsgebiet. Adulte ausdifferenzierte Hepatozyten werden nach einer Leberteilresektion zum Zellwachstum angeregt und proliferieren, bis die ursprüngliche Lebermasse wieder erreicht ist (Casado et al. 2001). Dabei spielen viele Faktoren, die sich gegenseitig beeinflussen, eine wichtige Rolle, wie z.B. freigesetzte Zytokine, Wachstumsfaktoren und Hormone (Fausto 2004). Nach Michalopoulos und DeFrances (1997) basiert der Regenerationsprozess auf der dynamischen Balance von positiven und negativen Stimuli. Nach Gallucci et al. (2000) werden TNFa und IL-6 nach Leberteilresektion 
schnell freigesetzt, die dadurch aktivierte NF-kB-Signalkaskade unterdrückt die Apoptose (Lavon et al. 2000; Rosenfeld et al. 2000). Eine erhöhte NO-Freisetzung und Induktion der iNOS nach Leberteilresektion wurde zuerst von Obolenskaya et al. 1994 beschrieben.

Zamora et al. (2001) beschrieben, dass die Expression von spezifisch apoptoseprotektiven Proteinen wie z.B. BNIP-3 oder Bcl-2 in B-Lymphozyten (Genaro et al. 1995) in Hepatozyten durch NO supprimiert wird. Sowohl Bcl-2 als auch BNIP-3 schützen vor mitochondraler Ausschüttung von pro-apoptotischen Molekülen. Des Weiteren beschrieben Ronco et al. (2004), dass exogen bedingte Induktion der iNOS und Behandlung durch den NO-Donator Natrium-Nitroprussid eine Erhöhung der Proteinspiegel des Bax-Proteins und des Proteins p53 zur Folge haben. Bax-Proteine fördern den Zelltod über Dimerisierung, und das p53-Protein hemmt als Produkt eines Tumorsuppressorgenes den Zellzyklus.

iNOS-knockout-Mäuse weisen eine signifikant gehemmte Leberregeneration durch verminderte Synthese von Hepatozyten-DNA, weniger Mitosen und abgeschwächtes Lebermassenwachstum auf. Außerdem entwickeln iNOS-knockout-Mäuse panlobuläre, mikrovesikuläre Fettakkumulationen in der Leber, begleitet von nekrotischen Zellabschnitten, polymorphkerniger Zellinfiltration und massiver Hepatozytenapoptose. Li Volti et al. (2005) zeigen, dass exogen und endogen zugeführtes NO nach einer Leberteilresektion die Hepatozyten vor Apoptose schützt. Die Aktivierung der Caspasen 8, 9 und 3, welche während des Zelluntergangs durch Apoptose eine bedeutende Rolle spielen, war beeinträchtigt, da Caspase 3 durch Nitrosylierung inaktiviert wird. Im Gegensatz dazu führt die Aktivierung der iNOS vor einer partiellen Hepatektomie jedoch zu einer stark verzögerten Leberregeneration (Zeini et al. 2005).

\section{Wirkung von exogen zugeführtem NO durch Gabe von NO-Donatoren}

Aufgrund der oben genannten zentralen Bedeutung von NO wurden viele NODonatoren entwickelt, um die Wirkungsweise von NO in in-vitro-Modellen genauer zu untersuchen. Leberspezifisch untersucht wurde in bisherigen Studien der NODonator Natrium-Nitroprussid (NNP), welcher in Tiermodellen vor TNFa-induzierten 
Leberschäden schützt (Bohlinger et al. 1995) und die Entzündungsantwort und Zytokinexpression reduziert (Anaya-Prado et al. 2003). Außerdem wirkt NNP protektiv bei LPS/IFNY-Toxizität evtl. durch Unterdrücken der Caspase-3-Aktivität (So et al. 2001).

Für unsere Untersuchungen wählten wir u.a. das wenig bekannte Furoxan CAS 1609 als NO-Donator aus. Hecker et al. berichteten 1995, dass CAS 1609 aus der Klasse der Furoxane eine langfristige Freisetzung von NO bewirkt und damit gleichzeitig eine starke vasodilatatorische Aktivität besitzt. Wie erst kürzlich erstmalig gezeigt, steigerte das Furoxan CAS 1609 die Proliferation kultivierter Hepatozyten um das Dreifache (Wätzig 2008, Krause et al. 2010).Als Kontrollsubstanz wurde das Furazan eingesetzt, das zur gleichen Substanzklasse gehört, aber im Gegensatz zu CAS 1609 kein NO freisetzt. Das Furazan wirkte nicht mitogen.

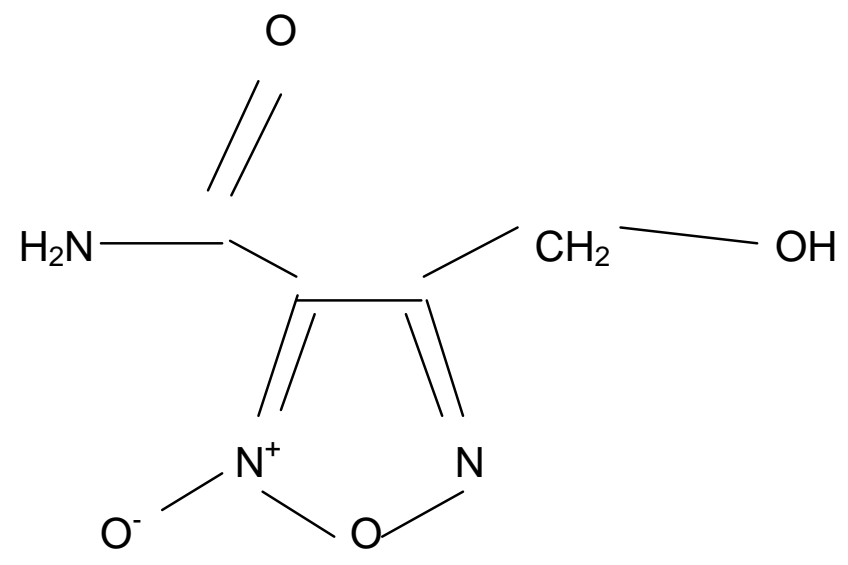

Strukturformel von CAS 1609 (4-Hydroxymethyl-Furoxan-3-Carboxyamid)

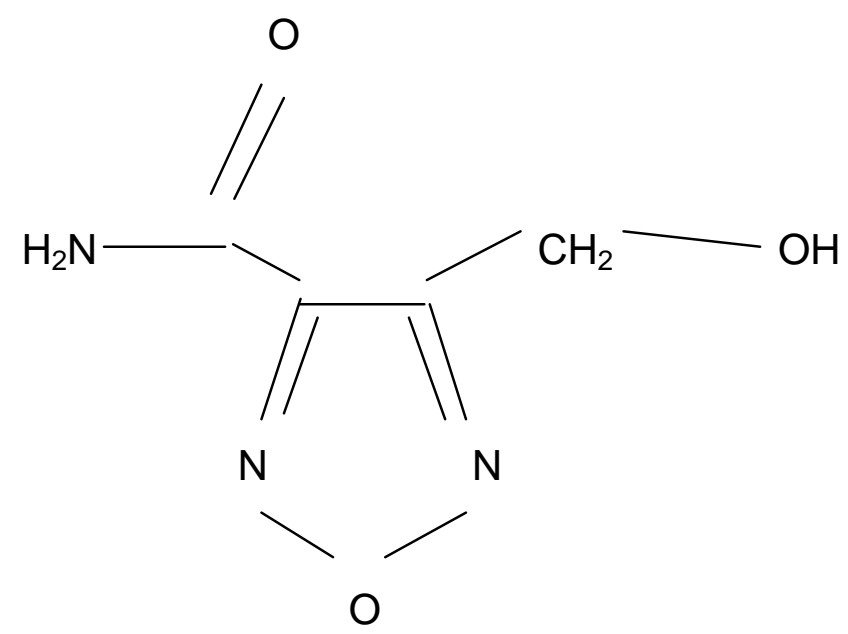

Strukturformel von C 93-4845 (4-Hydroxymethyl-Furazan-3-Carboxyamid) 


\section{Die Bedeutung von Kohlenstoffmonoxid für das Hepatozytenwachstum}

CO zeigt ähnliche physiologische Eigenschaften wie $N O$ in Bezug auf Apoptoseprotektion und Vasoregulation nach einer Leberteilresektion. Beide Gase sind in der Lage, sich gegenseitig zu beeinflussen. Ihr Zusammenspiel schützt die Hepatozyten vor TNFa-induzierter Apoptose, fördert die ausreichende Durchblutung und reduziert die Scherkräfte nach Leberteilresektion (Schuett et al. 2007).

\section{Die Isoformen von Hämoxygenase}

Die Hämoxygenase $(\mathrm{HO})$ katalysiert die Spaltung der Hämgruppe zwischen Ring $A$ und Ring B. Die Produkte sind Kohlenmonoxid, Biliverdin und Eisen. Die Hämoxygenase kommt in drei Isoformen vor: HO-1, HO-2 und HO-3 (Maines et al. 1986, Mempel et al. 2004, Tenhunen et al. 1968). Sie stammen aus verschiedenen Genen, differieren in ihrem Expressionsmuster und sind in unterschiedlichen Geweben verteilt. Sie werden auch unterschiedlich aktiviert und sind an mikrosomalen Membranen verankert (Maines 1988, Morse und Choi 2002, Otterbein und Choi 2000, Wagner et al. 2003). Hämoxygenase-Aktivität lässt sich in allen bisher untersuchten Geweben und Organen nachweisen und ist in der Milz am höchsten, wo der Abbau gealterter Erythrozyten mit der entsprechenden Freisetzung von Häm aus Hämoglobin stattfindet (Otterbein und Choi 2000). Die Aminosäuresequenzen der HO-2 und $\mathrm{HO}-3$ sind annähernd gleich, unterscheiden sich aber deutlich von der der HO-1 (McCoubrey et al. 1997). Diese Differenzen lassen die Vermutung zu, dass die HO-1 eine andere metabolische Funktion hat, als die Isoformen 2 und 3.

HO-2 und HO-3 sind konstitutive Isoformen der HO. Der Erstbeschreiber Maines (1988) meint, dass die HO-2 in der Leber physiologisch deutlich stärker aktiv ist als die HO-1. Die HO-2 kann durch Glukokortikoide und Opiate induziert werden (Li X und Clark 2000), die HO-2 findet man in den meisten Geweben, besonders im ZNS und den Hoden. HO-2 und HO-3 spielen als Stressproteine eine untergeordnete 
Rolle, ihre Funktion liegt in der Aufrechterhaltung der Homöostase des zellulären Häm- und Eisen- Haushaltes.

Die HO-1 ist in fast allen Geweben unter physiologischen Bedingungen nachzuweisen, sie wurde von Tenhunen et al. 1968 and 1969 beschrieben. Nur in der Milz, dem Hauptabbauort gealterter Erythrozyten, wird sie unter Normalbedingungen stärker exprimiert als die beiden anderen Isoformen. HO-1 ist durch eine größere Vielzahl an Stimuli induzierbar (Maines 1997) und wird auch als HSP-32 bezeichnet, da sie in die Gruppe der Hitzeschockproteine (HSP) gehört. Die Regulation der HO-1 ist zell- bzw. gewebespezifisch und findet auf der Ebene der Transkription statt (Maines 1988). Die HO-1 kann durch eine Vielzahl von Stimuli so stark induziert werden, dass ihre maximale Reaktionsgeschwindigkeit die der HO-2 um das ca. Zehnfache übertrifft. Neben Häm sind auch Schwermetalle, Protoporphyrine, bakterielle Lipopolysaccharide, Hypoxie, Hyperoxie, Hitzeschock, Ischämie und Reperfusion, UV-Bestrahlung, $\mathrm{H}_{2} \mathrm{O}_{2}$, NO, Zytokine und Substanzen, die die zellulären Glutathion-Speicher entleeren, an der Induktion der HO-1 beteiligt (Otterbein und Choi 2000). Alle diese Stimuli besitzen auch die Fähigkeit, Sauerstoffradikale zu bilden, so dass man vermuten kann, dass die HO-1 eine Rolle in der Regulation des Reduktionszustandes der Zelle spielt.

\section{Die Endprodukte von Hämoxygenase}

Eisen ist ein Spurenelement im menschlichen Körper, welches mit der Nahrung aufgenommen und in verschiedene Proteine eingebaut wird (Hämoglobin, Myoglobin, Cytochrom, Enzyme). Durch den Darm wird es resorbiert, in Form von Ferritin in den Zellen gespeichert und gebunden an Transferrin im Blut transportiert. Zweiwertiges Eisen $\left(\mathrm{Fe}^{2+}\right)$, das bei der Ringspaltung des Häm-Moleküls freigesetzt wird, wird zum $\mathrm{Fe}^{3+}$ oxidiert. Bei dieser Fenton-Reaktion, entsteht aus $\mathrm{H}_{2} \mathrm{O}_{2}$ das hochreaktive Hydroxyl-Radikal $(\cdot \mathrm{OH})$. Dieses wiederum führt letztlich zu Lipid-Peroxidationen und zu Zell- und Gewebeschädigung (Gutteridge 1995). Biliverdin wird durch die Biliverdin-Reduktase zu Bilirubin umgewandelt. Bilirubin wird an Albumin gebunden, zur Leber transportiert und dort, konjugiert mit Glucuronsäure, über die 
Gallenflüssigkeit ausgeschieden. Biliverdin wirkt antioxidativ und schützt somit die Gefäße vor Oxidation (Baranano et al. 2002). Wie NO verdrängt Kohlenmonoxid (CO) den Sauerstoff von Hämoglobin und bildet Carboxy-Hämoglobin (CO-Hb) (Thews et al. 2000). Dadurch kommt es zu einem Sauerstoffmangel in den Geweben, kapillärer Dilatation und Blutdruckabfall (Penney 1988). Zusätzlich wird die lösliche Form der Guanylat-Cyclase (sGC) durch Kohlenstoffmonoxid aktiviert (Kharitonov et al. 1995), dies führt so zur Vasorelaxation (Furchgott und Jothianandan 1991). CO wirkt in Signaltransduktionsketten und hemmt die Thrombozytenaggregation (Lindenblatt et al. 2004, Wagner et al. 2003).

\section{Die Bedeutung von CO bei der Leberregeneration}

Wie NO so wirkt auch CO hepatoprotektiv und verhindert die Apoptose in kultivierten Hepatozyten (Choi et al. 2008). Nach Teilhepatektomie wird die Genexpression der HO-1 erhöht (Srivastava et al. 1982, Yoshida et al. 1984, Schuett et al. 2007). Präoperative Gabe des HO-1-Induktors Kobaltprotoporphyrin (CoPP) entweder alleine (Glanemann et al. 2005) oder in Kombination mit dem NOS-Inhibitor L-NAME (Schuett et al. 2007) erhöhte den mitotischen Index der Hepatozyten. Dies weist auf eine wachstumsfördernde Funktion von $\mathrm{CO}$ in vivo hin. Eine erhöhte in-vitroProliferation nach Gabe eines CO-Donors (CORM-3) wurde erst kürzlich für kultivierte Endothelzellen beschrieben (Vadori et al. 2009).

\section{Fragestellung und Ziele}

Die Rolle von NO und CO für das in-vivo-Wachstum von Hepatozyten nach einer Leberteilresektion wurde von Schuett et al. (2007) untersucht. Aber es existieren wenige Daten zur Bedeutung der NO-Synthase und keine Daten zur Rolle der Hämoxygenase-1 für die in-vitro-Proliferation von isolierten Hepatozyten.

In dieser Arbeit soll geklärt werden, ob die iNOS und die Hämoxygenase-1 eine Rolle für das in-vitro-Wachstum von Hepatozyten in Primärkultur spielen. 
Folgende Fragen sollen beantwortet werden:

1. Gibt es einen funktionellen Zusammenhang zwischen der Proliferationsrate der Hepatozyten und der iNOS-mRNA-Menge und NO-Synthase-Aktivität?

2. Hat CAS 1609 einen Einfluss auf die Expression der Hämoxygenase-1?

3. Kann das in-vitro-Wachstum von Hepatozyten durch die CO-bildende Substanz CORM 2 erhöht werden?

Abschließend wurde ein in-vitro-Protokoll für die Kultivierung proliferierender Maushepatozyten ausgearbeitet, um so die Untersuchungen vom Ratten- auf das Maus-Modell ausdehnen zu können. 


\section{Material und Methoden}

\subsection{Tiere und Tierhaltung}

Aus der zentralen Tiereinrichtung des Klinikums Göttingen wurden männliche WistarRatten (200-250 g) und männliche Black-6-Mäuse (6-12 Monate) für die Experimente zur Verfügung gestellt. Die Tiere waren auf einen 12-h-Hell/Dunkelrhythmus eingestellt. Ihr Futter bestand aus Diät der Firma Sniff (Soest), welches den Tieren frei zugänglich war. Die Ratten wurden in der Hellphase durch peritoneale Injektion von Nembutal $(60 \mathrm{mg} / \mathrm{kg})$, unter das Bauchfell narkotisiert, die Mause durch $400 \mu \mathrm{l}$ einer Lösung von $10 \mathrm{mg}$ Nembutal $/ \mathrm{ml}$.

2.2 Isolierung von Hepatozyten

\subsubsection{Medien}

Krebs-Ringer-Lösung $(\mathrm{pH} 7,35)$

$\begin{array}{lrl}\mathrm{NaCl} & 120,0 \mathrm{mM} & 7,00 \mathrm{~g} / \mathrm{l} \\ \mathrm{KCl} & 4,8 \mathrm{mM} & 0,36 \mathrm{~g} / \mathrm{l} \\ \mathrm{MgSO}_{4} \times 7 \mathrm{H}_{2} \mathrm{O} & 1,2 \mathrm{mM} & 0,296 \mathrm{~g} / \mathrm{l} \\ \mathrm{KH}_{2} \mathrm{PO}_{4} & 1,2 \mathrm{mM} & 0,163 \mathrm{~g} / \mathrm{l} \\ \mathrm{NaHCO}_{3} & 24,0 \mathrm{mM} & 2,016 \mathrm{~g} / \mathrm{l}\end{array}$

Präperfusionslösung
EGTA
$0,25 \mathrm{mM}$
$100,0 \mathrm{mg} / \mathrm{l}$

gelöst in Krebs-Ringer-Lösung

Perfusionsmedium ( $\mathrm{pH} 7,4)$ (nach Meredith 1988)

$\begin{array}{lrl}\mathrm{NaCl} & 140,0 \mathrm{mM} & 6,75 \mathrm{~g} / \mathrm{l} \\ \mathrm{KCl} & 4,8 \mathrm{mM} & 0,360 \mathrm{~g} / \mathrm{l} \\ \mathrm{MgCl}_{2} \times 6 \mathrm{H}_{2} \mathrm{O} & 0,8 \mathrm{mM} & 0,163 \mathrm{~g} / \mathrm{l} \\ \mathrm{Na}_{2} \mathrm{HPO}_{4} \times 2 \mathrm{H}_{2} \mathrm{O} & 1,6 \mathrm{mM} & 0,285 \mathrm{~g} / \mathrm{l} \\ \mathrm{KH}_{2} \mathrm{PO}_{4} & 0,4 \mathrm{mM} & 0,055 \mathrm{~g} / \mathrm{l} \\ \mathrm{NaHCO}_{3} & 25,0 \mathrm{mM} & 2,1 \mathrm{~g} / \mathrm{l}\end{array}$




$\begin{array}{lrr}\text { EDTA } & 2,0 \mathrm{mM} & 0,585 \mathrm{~g} / \mathrm{l} \\ \text { Glucose } & 15,0 \mathrm{mM} & 2,975 \mathrm{~g} / \mathrm{l} \\ \text { Hepes } & 15,0 \mathrm{mM} & 3,575 \mathrm{~g} / \mathrm{l} \\ \text { Lactat } & 2,0 \mathrm{mM} & 0,224 \mathrm{~g} / \mathrm{l} \\ \text { Pyruvat } & 0,2 \mathrm{mM} & 0,022 \mathrm{~g} / \mathrm{l}\end{array}$

Perfusionsmedium für die Zellpräparation mit Kollagenase $(\mathrm{pH} 7,4)$

$\begin{array}{lrl}\text { Hepes } & 15,0 \mathrm{mM} & 3,356 \mathrm{~g} / \mathrm{l} \\ \mathrm{CaCl}_{2} & 4,0 \mathrm{mM} & 0,588 \mathrm{~g} / \mathrm{l} \\ \text { Kollagenase } & & 0,50 \mathrm{~g} / \mathrm{l}\end{array}$

Gelöst in Krebs-Ringer-Lösung, äquilibriert mit Carbogen

Stammpuffer für die Percollgradienten-Zentrifugation ( $\mathrm{pH}$ 3-4)

\begin{tabular}{lrr}
$\mathrm{NaCl}$ & \multicolumn{1}{c}{$1,4 \mathrm{M}$} & $81,8 \mathrm{~g} / \mathrm{l}$ \\
$\mathrm{KCl}$ & $50,0 \mathrm{mM}$ & $3,7 \mathrm{~g} / \mathrm{l}$ \\
$\mathrm{MgCl}_{2} \times 6 \mathrm{H}_{2} \mathrm{O}$ & $8,0 \mathrm{mM}$ & $1,63 \mathrm{~g} / \mathrm{l}$ \\
$\mathrm{Na}_{2} \mathrm{HPO}_{4} \times 6 \mathrm{H}_{2} \mathrm{O}$ & $16,0 \mathrm{mM}$ & $2,8 \mathrm{~g} / \mathrm{l}$ \\
$\mathrm{KH}_{2} \mathrm{PO}_{4}$ & $4,0 \mathrm{mM}$ & $0,54 \mathrm{~g} / \mathrm{l}$ \\
gelöst in $\mathrm{H}_{2} \mathrm{O}$ & &
\end{tabular}

\subsubsection{Perfusion der Leber}

Die Präparation und die anschließende Perfusion der Leber wurden unter aseptischen Bedingungen vorgenommen.

\section{Offene Perfusion der Leber}

Durch einen medianen Längsschnitt wurde das Abdomen geöffnet. Die Braunülen wurden mit lockeren Ligaturen an der V. portae und V. cava inferior fixiert. Die V. cava superior wurde zur besseren Durchspülung der Leber abgebunden. Die erste Braunüle wurde in die V. portae gestochen und dort fixiert. Zur Druckentlastung wurde die V. cava inferior mit einer Schere durchtrennt und unmittelbar daran das Präperfusionsmedium über die $\mathrm{V}$. portae in die Leber eingeleitet. Dabei wurde sie mit $250 \mathrm{ml}$ Präperfusionslösung $\left(37^{\circ} \mathrm{C}\right)$ blutleer gespült. 
Danach wurde die Leber mit weiteren 2l Perfusionslösung (Ratte) oder $500 \mathrm{ml}$ (Maus) durchspült. Zur Isolierung von Rattenhepatozyten wurde die zweite Braunüle in die V. cava inferior gelegt, um das Perfusionsmedium abfließen zu lassen. Dabei wurde die Leber mit einer Durchflussgeschwindigkeit von $40 \mathrm{ml} / \mathrm{min}$ perfundiert. Auf diese Weise wurde die Rattenleber für 35-45 min mit dem Perfusionsmedium durchgespült. Die Perfusion der Mausleber verlief ohne Braunüle in der V. cava inferior, die Durchflussgeschwindigkeit betrug ca. 10-12 ml/min.

\subsubsection{Herstellung der Hepatozyten-Zellsuspension}

Nach der Perfusion wurde die Leber entnommen und in eine Schale mit Williams-EKulturmedium überführt. Danach wurde die Leber mit zwei Pinzetten zerrissen und die Leberzellen durch kräftiges Schütteln aus dem Gewebe gelöst, bis sich eine Zellsuspension bildete, die durch ein Nylonnetz filtriert wurde. Nach 2-maligem Waschen mit Williams-E-Medium und Zentrifugieren der Zellen (500 Upm, 4 min) wurden $25 \mathrm{ml}$ Zellsuspension in Medium mit $43 \mathrm{ml}$ Percoll (Pharmacia No. 17-089101) und $6,5 \mathrm{ml}$ Stammpuffer vermischt und zentrifugiert (2.200 Upm, $5 \mathrm{~min}$ ). Die Zelltrümmer und tote Zellen schwammen auf dem Percollgradienten, das Zellsediment aus vitalen Hepatozyten wurde nun aufgenommen und erneut mit Kulturmedium gewaschen.

Das Sediment des letzten Zentrifugationsganges wurde in Williams-E-Medium aufgenommen. Das Medium enthielt zusätzlich 10\% fötales Kälberserum (FCS), 1\% Gentamycin $(50 \mu \mathrm{g} / \mathrm{ml}), 10^{-8} \mathrm{M}$ Insulin und $10^{-7} \mathrm{M}$ Dexamethason. Anschließend erfolgte die Ausplattierung von $1,5 \mathrm{ml}$ der Hepatozyten-Zellsuspension auf Kollagengele, in 3,5 cm Kulturplatten. Plattiert wurden 50000 Rattenhepatozyten und 30000 Maushepatozyten.

\subsubsection{Herstellung der Stromalzellen-Zellsuspension}

\section{Geschlossene Perfusion der Leber (Kollagenase-Präparation)}

Nach der Präperfusion (siehe oben) wurde eine zweite Braunüle in die eröffnete Vena cava inferior gelegt und fixiert. Hierüber konnte das Perfusionsmedium in ein Sammelgefäß zurückgeführt werden. Von dort aus durchströmte es einen Oxygenator, wo das Medium mit Carbogen begast und auf $37^{\circ} \mathrm{C}$ erwärmt wurde. 
Anschließend floss das Perfusionsmedium mit einem Fluss von $20 \mathrm{ml} / \mathrm{min}$ erneut in die Portalvene ein.

Auf diese Weise wurde die Leber 5 min rezirkulierend mit dem kollagenasehaltigen Perfusionsmedium perfundiert.

Nach Zerreißen der Leberkapsel und Filtrieren der entstandenen Zellsuspension durch das Nylonnetz wurde der Überstand mit den Nichtparenchym (=Stromal)Zellen nach dem ersten Zentrifugieren (500 Upm, 4 min) vorsichtig in vier $50 \mathrm{ml}$ Röhrchen überführt und erneut zentrifugiert (600 Upm, $4 \mathrm{~min}$ ), um restliche eingeschleppte Hepatozyten auszusondern. Die Stromalzellen wurden mit 1.300 Upm $10 \mathrm{~min}$. sedimentiert, in Williams-E-Medium aufgenommen und so die vier Sedimente vereinigt. Die Zellsuspension wurde erneut durch Zentrifugation (1.300Upm, $10 \mathrm{~min}$ ) von Zelltrümmern befreit.

Das Stromalzellsediment wurde nun in Williams-E-Medium aufgenommen und zusätzlich mit 15\% FCS und 1\% Gentamycin versetzt.

\subsection{Medien und Stammlösungen}

\section{Williams-E-Medium}

Pulvermedium mit 5mM Glucose

$\begin{array}{lcc}\text { Hepes } & 15,0 \mathrm{mM} & 3,58 \mathrm{~g} / \mathrm{I} \\ \mathrm{NaHCO}_{3} & 26,2 \mathrm{mM} & 2,2 \mathrm{~g} / \mathrm{I} \\ \mathrm{BSA} & 0,2 \% & 2,0 \mathrm{~g} / \mathrm{I} \\ \text { O-Phosphoethanolamin } & 0,1 \mathrm{mM} & 14 \mathrm{mg} / \mathrm{I} \\ \text { Aminoethanol } & 0,1 \mathrm{mM} & 10 \mathrm{mg} / \mathrm{I} \\ \text { Na-Selenit } & 7,5 \mathrm{nM} & 0,5 \mathrm{ml} / \mathrm{I}\end{array}$

Die Pulvermedien wurden in Wasser gelöst und der pH-Wert auf 7,35 eingestellt. Nach der Begasung von ca. 3 Stunden wurde der pH-Wert erneut auf 7,35 eingestellt. Die Medien wurden erst über den Faltenfilter und anschließend steril filtriert, wo sie bei $4^{\circ} \mathrm{C}$ aufbewahrt wurden. 
Grundmedium

Williams-E-Medium

$80,0 \mathrm{ml} / 100 \mathrm{ml}$

Insulin

$2 \times 10^{-7} \mathrm{M}$

$2 \mathrm{ml} / 100 \mathrm{ml}$

Dexamethason

$2 \times 10^{-7} \mathrm{M}$

$0,2 \mathrm{ml} / 100 \mathrm{ml}$

Gentamycin

$50 \mu \mathrm{g} / \mathrm{ml}$

$1 \mathrm{ml} / 100 \mathrm{ml}$

Hydrocortison

$10^{-7} \mathrm{M}$

$0,1 \mathrm{ml} / 100 \mathrm{ml}$

Transferrin

$5 \mu \mathrm{g} / \mathrm{ml}$

$0,1 \mathrm{ml} / 100 \mathrm{ml}$

Heparin

$10 \mu \mathrm{g} / \mathrm{ml}$

$0,1 \mathrm{ml} / 100 \mathrm{ml}$

EGF

10ng / ml

$0,1 \mathrm{ml} / 100 \mathrm{ml}$

FGFb

$5 \mathrm{ng} / \mathrm{ml}$

$0,05 \mathrm{ml} / 100 \mathrm{ml}$

\section{Geliermedium}

Pulvermedium RPMI

$\begin{array}{lrr}\text { Hepes } & 75,0 \mathrm{mM} & 3,57 \mathrm{~g} / 200 \mathrm{ml} \\ \mathrm{NaHCO}_{3} & 89,0 \mathrm{mM} & 1,5 \mathrm{~g} / 200 \mathrm{ml}\end{array}$

Die Pulvermedien wurden in $200 \mathrm{ml}$ Wasser gelöst und der pH-Wert auf 9,0 eingestellt. Anschließend wurde das Medium steril filtriert und bei $4^{\circ} \mathrm{C}$ aufbewahrt.

\section{Stammlösungen}

Alle genannten Stammlösungen wurden nach dem Ansetzen steril filtriert und bei $20^{\circ} \mathrm{C}$ aufbewahrt.

Hydrocortison

Hydrocortison $\quad 10^{-4} \mathrm{M} \quad 5,0 \mathrm{mg} / 100 \mathrm{ml}$

$5 \mathrm{mg}$ Hydrocortison wurden in 0,2 $\mathrm{ml}$ Ethanol gelöst. Anschließend wurde das Volumen auf $100 \mathrm{ml}$ mit 0,9\% NaCl aufgefüllt.

Transferrin

Transferrin $\quad 5 \mathrm{mg} / \mathrm{ml} \quad 100 \mathrm{mg} / 20 \mathrm{ml}$

in PBS mit $0,1 \%$ BSA 
Heparin

Heparin

$10 \mathrm{mg} / \mathrm{ml} \quad 100 \mathrm{mg} / 10 \mathrm{ml}$

in $0,9 \% \mathrm{NaCl}$-Lösung

Antibiotikum-Stammlösung

Gentamycin

$5,0 \mathrm{~g} / \mathrm{l}$

in $0,9 \% \mathrm{NaCl}$-Lösung

$\underline{E G F}$

EGF

$10 \mu \mathrm{g} / \mathrm{ml} \quad 100 \mu \mathrm{g} / 10 \mathrm{ml}$

in $0,9 \% \mathrm{NaCl}$-Lösung mit $0,1 \% \mathrm{BSA}$

\section{$\underline{F G F}$}

FGFb

$10 \mu \mathrm{g} / \mathrm{ml} \quad 25 \mu \mathrm{g} / 2,5 \mathrm{ml}$

in $10 \mathrm{mM}$ Tris mit $0,1 \%$ BSA, Einstellung des $\mathrm{pH}$-Wertes auf 7,5

Nicotinamid

Nicotinamid

$1 \mathrm{M}$

$3,05 \mathrm{~g} / 25 \mathrm{ml}$

in $\mathrm{H}_{2} \mathrm{O}$

Ascorbat-2-Phosphat

Ascorbat-2-Phosphat

$0,2 \mathrm{M}$

$1,7 \mathrm{~g} / 25 \mathrm{ml}$

in $\mathrm{H}_{2} \mathrm{O}$

$\underline{\text { Insulin }}$

Insulin

$10^{-5} \mathrm{M}$

$3,0 \mathrm{mg} / 50 \mathrm{ml}$

BSA

$50 \mathrm{mg} / 50 \mathrm{ml}$

Das Insulin wurde bei einem pH-Wert von 2,8 gelöst, die Lösung wurde dann neutralisiert und Rinderserumalbumin hinzugegeben. 
Dexamethason

Dexamethason

$10^{-4} \mathrm{M} \quad 4,0 \mathrm{mg} / 100 \mathrm{ml}$

in $0,9 \% \mathrm{NaCl}$-Lösung

$4 \mathrm{mg}$ Dexamethason wurden zunächst in 0,6 ml Ethanol p.a. gelöst.

Anschließend wurde das Volumen auf $100 \mathrm{ml}$ mit $0,9 \% \mathrm{NaCl}$ aufgefüllt.

CAS 1609

CAS 1609

$100 \mathrm{mM}$

$15,91 \mathrm{mg} / \mathrm{ml}$

in $\mathrm{H}_{2} \mathrm{O}$

Diese Stammlösung wurde kurz vor dem Experiment aufgetaut und mit Kulturmedium im Verhältnis 1:10 verdünnt.

\subsection{Anheftung und Kultivierung von Hepatozyten}

Auf die Kollagengele in $\varnothing 3,5-\mathrm{cm}$-Kulturplatten wurden $1,5 \mathrm{ml}$ (50.000 Zellen) der Hepatozyten-Zellsuspension pipettiert und bei $37^{\circ} \mathrm{C}$ im Brutschrank mit $5 \% \mathrm{CO}_{2}$ in Luft inkubiert.

Die Zellen hafteten auf dem Gel und nach Ablauf von vier Stunden wurde der erste Medienwechsel durchgeführt. Das Medium wurde abgesaugt und die Zellen, je nach Experiment, mit speziell angefertigten Experimentiermedien versetzt. Weitere Mediumwechsel wurden nach jeweils $24 \mathrm{~h}$ Inkubationsdauer durchgeführt.

\subsection{Herstellung von konditionierten Kulturmedien}

\subsubsection{Gewinnung von Stromalzell-konditioniertem Medium (SZ-CM)}

Kulturplatten $(\varnothing 6 \mathrm{~cm})$ mit $1 \%$ Glutaraldehyd quervernetztem Kollagengel wurden mit $3,0 \mathrm{ml}$ Stromalzellsuspension benetzt, um koloniestimulierendes Medium zu gewinnen. Der erste Mediumwechsel erfolgte nach drei Stunden. Das Medium wurde dabei vorsichtig abgesaugt und jede Platte zweimal mit Williams-E-Medium gewaschen. Später wurde auf jede Kulturplatte ein Gemisch aus $2 \mathrm{ml}$ Grundmedium mit $1 \mathrm{ml}$ Hepatozyten-konditioniertem Medium pipettiert. 
Die folgenden Mediumwechsel erfolgten alle zwei Tage. Von Tag 6 bis Tag 14 wurden die jeweils konditionierten Medien von den Zellkulturplatten abpipettiert, vereinigt, steril filtriert und bei $4^{\circ} \mathrm{C}$ aufbewahrt.

\subsubsection{Gewinnung von Hepatozyten-konditioniertem Medium (HCM)}

Um Hepatozyten-konditioniertes Medium herzustellen, wurden kollagenbeschichtete $\varnothing$ 10-cm-Kulturplatten mit 7,5ml Hepatozyten-Zellsuspension benetzt. Nach Ablauf von vier Stunden wurden die Zellen zweimal mit Williams-E-Medium gewaschen. Die Zellen erhielten Williams E-Medium mit Gentamycin (1\%), $10^{-9}$ Insulin, $10^{-7} \mathrm{M}$ Dexamethason, $10^{-7} \mathrm{M}$ Hydrocortison. Nach weiteren $20 \mathrm{~h}$ Inkubationszeit wurde das entstandene Medium mit der Pipette entnommen und in Röhrchen gesammelt, danach steril filtriert und bei $-20^{\circ} \mathrm{C}$ aufbewahrt.

\subsection{Kollagenherstellung}

Aus Rattenschwänzen wurden die Kollagenfasern gewonnen und für ca. zwei Stunden auf Aluminiumfolie getrocknet und danach in $2 \mathrm{~cm}$ lange Stücke geschnitten. Die Fasern (1 $\mathrm{g})$ wurden in je $300 \mathrm{ml}$ Essigsäure (1:1.000 verdünnt) für $24 \mathrm{~h}$ bei $6^{\circ} \mathrm{C}$ im Kühlraum gerührt.

Die Lösung wurde bei 11.000 Upm 2 h zentrifugiert (Sorvall, GSA- Rotor), der visköse Überstand vorsichtig abgegossen und bei $4^{\circ} \mathrm{C}$ aufbewahrt.

Für die Beschichtung der $\varnothing 3,5$-cm-Zellkulturplatte wurden $75 \mu \mathrm{l}$ Geliermedium auf jede Platte pipettiert und mit $300 \mu \mathrm{l} \mathrm{Kollagen} \mathrm{gemischt.} \mathrm{Sofort} \mathrm{wurde} \mathrm{es} \mathrm{auf} \mathrm{der} \mathrm{Platte}$ verteilt. Nach 30 min Inkubationszeit im Brutschrank bei $37^{\circ} \mathrm{C}$ wurden die gelierten Kollagengele mit je 1,5ml Williams-E-Medium überschichtet und im Brutschrank bis zu Beginn des Experiments inkubiert.

Quervernetzung: Das Kollagen wurde bei Raumtemperatur mit 1\% Glutaraldehyd über zwei Stunden gerührt und über 7 Tage gegen 1:1.000 verdünnte Essigsäure dialysiert. 


\subsection{Quantitative Bestimmung des DNA-Gehaltes}

DNA-Farbstofflösung

Bis-Benzimid

$3,0 \mathrm{mg} / 1$

Es wurde in DNA-Testpuffer gelöst und 3-5 h lichtgeschützt gerührt.

DNA-Testpuffer

$\begin{array}{lll}\mathrm{Na}_{2} \mathrm{HPO}_{4} \text {-Base } & 50 \mathrm{mM} & 8,9 \mathrm{~g} / \mathrm{I} \\ \mathrm{NaH}_{2} \mathrm{PO}_{4} \text {-Säure } & 50 \mathrm{mM} & 6,9 \mathrm{~g} / \mathrm{I}\end{array}$

gelöst in $2 \mathrm{M} \mathrm{NaCl}$

Base mit Säure auf pH-Wert 7,4 eingestellt.

Um den DNA-Gehalt der Hepatozyten auf den Platten zu bestimmen, wurden diese zweimal mit $0,9 \% \mathrm{NaCl}$ gewaschen und bei $-20^{\circ} \mathrm{C}$ eingefroren. Für die Messung wurde der Zellrasen mit $1 \mathrm{ml}$ DNA-Testpuffer mit einem Gummispatel abgekratzt, in ein 1,5-ml-Eppendorf-Cup pipettiert und anschließend für $10 \mathrm{~s}$ mit dem Ultraschallgerät beschallt. 100-500 $\mu \mathrm{l}$ Proben wurden mit DNA-Testpuffer auf $1 \mathrm{ml}$ aufgefüllt und mit $1 \mathrm{ml}$ DNA-Farbstofflösung versetzt. Nach einer Inkubationszeit im Dunkeln von 30 min erfolgte die Messung im Fluorimeter bei einer Exzitation von 360nm gegen einen Leerwert. Die Eichkurve wurde mit einer DNA-StandardDoppelbestimmung im DNA-Testpuffer im Bereich von 0 bis $2,5 \mu \mathrm{g}$ DNA / ml erstellt.

\subsection{Bestimmung der Menge an HO-1 und iNOS m-RNA durch quantitative realtime $P C R$}

\section{RNA Isolierung}

Die Isolierung der RNA aus den Zellen wurde mit dem RNeasy Mini Kit (Qiagen) durchgeführt, dabei wurde nach Protokoll gearbeitet. Dieses Kit enthält die Puffer RPE, RW1 und RLT, deren Zusammensetzung vom Hersteller nicht bekannt gegeben wurde. Das Nährmedium wurde abgesaugt und $600 \mu \mathrm{l}$ RLT-Puffer auf die Zellen gegeben. Dieser bewirkt das Lysieren der Zellen, und das im RLT-Puffer enthaltene Guanidin-Isothiocyanat inaktiviert RNasen. Die Konzentration der abschließend in $40 \mu \mathrm{l}$ RNase-freiem Wasser vorliegenden RNA wurde zunächst photometrisch gemessen. Die Proben wurden bis zur quantitativen Bestimmung bei $-80^{\circ} \mathrm{C}$ gelagert. 


\section{Photometrische Konzentrationsbestimmung}

Die Nukleinsäurekonzentration wurde photometrisch bei $260 \mathrm{~nm}$ bestimmt.

Die Konzentration ergibt sich aus dem Lambert-Beer`schen-Gesetz:

Lambert-Beer-Gesetz: $\quad E \lambda=\epsilon \lambda \cdot c \cdot d$

$\mathrm{E} \lambda=$ Extinktion bei der Wellenlänge $\lambda$

$\varepsilon \lambda=$ molarer Extinktionskoeffizient bei der Wellenlänge $\lambda$

in $\mathrm{M}^{-1}$

$\mathrm{c}=$ Konzentration der Teilchen in der Lösung in $\mathrm{mol} / \mathrm{l}$

$\mathrm{d}=$ Schichtdicke der durchstrahlten Lösung in $\mathrm{cm}$

Für die Berechnung der Nukleinsäurekonzentration lautet die abgeleitete Formel:

$$
\begin{aligned}
& c=E_{260} \cdot k / d \\
& c=\text { Konzentration der Nukleinsäure in } \mu \mathrm{g} / \mathrm{ml} \\
& E_{260}=\text { Extinktion bei } 260 \mathrm{~nm} \\
& d=0,5 \mathrm{~cm} \text { (Dicke der verwendeten Quarzglas-Küvette) } \\
& k=\text { nukleinsäurespezifischer Koeffizient in } \mu \mathrm{g} / \mathrm{ml}
\end{aligned}
$$

Werte für $\mathrm{k}$ :

$$
\begin{array}{ll}
\text { dsDNA: } & 50 \mu \mathrm{g} / \mathrm{ml} \text { (ds = double strain) } \\
\text { ssDNA: } & 33 \mu \mathrm{g} / \mathrm{ml} \text { (ss = single strain }) \\
\text { RNA: } & 40 \mu \mathrm{g} / \mathrm{ml}
\end{array}
$$

Mittels einer weiteren Messung der Extinktion bei einer Wellenlänge von $280 \mathrm{~nm}$, dem Absorptionsmaximum der meisten Proteine, lässt sich der Quotient $E_{260} / E_{280}$ berechnen.

Mit diesem kann man die Reinheit einer Nukleinsäurelösung beurteilen. Er sollte einen Wert zwischen 1,6 und 2,0 annehmen. Außerdem kann durch eine Messung bei $230 \mathrm{~nm}$ der Salzgehalt der Probe bewertet werden. 


\section{Synthese der cDNA}

Die Synthese der cDNA erfolgte mit Hilfe des iScript-cDNA-Synthesis-Kits von BioRad nach Herstellerangaben. Für jede Probe wurden 400ng Gesamt-RNA eingesetzt:

$5 x$ iScript Reaction Mix $4 \mu l$

iScript reverse Transcriptase

$1 \mu \mathrm{l}$

Gesamt-RNA

400ng

Nukleasefreies Wasser ad $20 \mu \mathrm{l}$.

Das Gemisch wurde 5 min bei $25^{\circ} \mathrm{C}$ und anschließend 30 min bei $42^{\circ} \mathrm{C}$ inkubiert und zuletzt für 5 min bei $85^{\circ} \mathrm{C}$ inkubiert. Bei $4^{\circ} \mathrm{C}$ wurden die Proben gelagert.

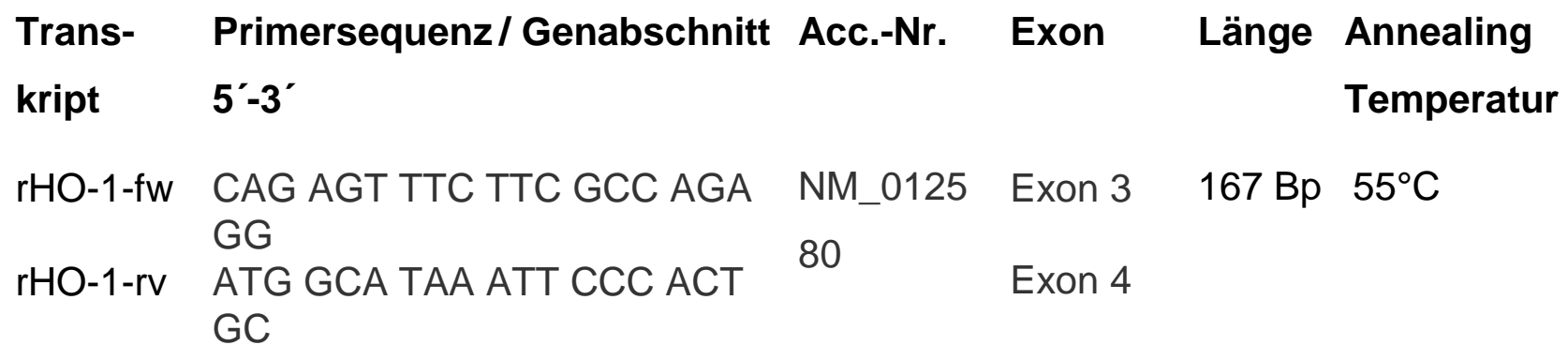

$\beta_{2} \mathrm{MG}$ fw GGT GAC CGT GAT CTT TCT NM_0125 Exon $1 \quad 145 \mathrm{Bp} \quad 61^{\circ} \mathrm{C}$ GG $12.1 \quad$ Exon 2

$\beta_{2}$-MG-rv TGG GTG GAA CTG AGA CAC

$\mathrm{G}$

rPBGD- CATGTATGCTGTGGGTCAGG X06827.1 Exon $203 \mathrm{Bp} \quad 60^{\circ} \mathrm{C}$ $\mathrm{fW}$ $10+11$

rPBGD-rv TCAGGTACAGTTGCCCATCC Exon 


\section{Darstellung der quantitativen real time $R T-P C R$}

Die real time RT-PCR ermöglicht die Analyse von RT-PCRs in Echtzeit. Alle quantitativen RT-PCR-Analysen wurden in einem iCycler iQ (Bio-Rad, München, Deutschland) ausgeführt, der von der computerunterstützen Real-Time PCR Detection System Software Version 3.0A gesteuert wurde. Diese Software konnte über Benutzeroberflächen mit Programmvorgaben für jede PCR versehen werden und ermöglichte die rechnerische und graphische Analyse während und nach Abschluss einer jeden RT-PCR. Die quantitative Detektion der RT-PCR-Produkte in Echtzeit erfolgte mit dem Fluoreszenzfarbstoff Sybr Green I ${ }^{\mathrm{TM}}$ als Reportermolekül. Sybr Green interkaliert sequenzunabhängig in doppelsträngige DNA-Moleküle, wobei bei Lichtanregung im Bereich von 490nm Licht von einer Wellenlänge im Bereich von $530 \mathrm{~nm}$ emittiert wird. Die Lichtanregung und Emissionsdetektion erfolgte durch das optische System des iCyclers jeweils während der Anlagerungsschritte eines jeden PCR-Zyklus. Die Stärke der emittierten Fluoreszenzsignale ist proportional zur Menge der zum jeweiligen Zeitpunkt in doppelsträngige DNA interkalierenden Sybr Green-Moleküle. Allerdings kann das Aufnahmesystem des iCyclers nur in der späten exponentiellen Phase einer PCR die Zunahme der Fluoreszenzemission, skaliert als Relative Fluorescence Units (RFU), detektieren. Nach der späten exponentiellen Phase geht die PCR in eine lineare Sättigungskurve über. Nach Ablauf einer PCR korrigiert die iCycler Software die in den ersten Zyklen einer PCR detektierten basalen Fluoreszenzintensitäten auf einen für alle PCR-Ansätze gleichen Nullwert. Dieser Schwellenwert definiert für jeden PCR Ansatz den Treshold Cycle (Schwellenwert-Zyklus), bei dem die Fluoreszenzintensität einer Probe den Schwellenwert durchschneidet und der durch die Standardkurve quantifiziert wird. Der Treshold Cycle ist in Zyklus-Einheiten mit der Genauigkeitsangabe von 1/10 Zyklus skaliert. Die Festsetzung des Schwellenwerts kann manuell erfolgen.

In Anschluss an jede quantitative RT-PCR wurde eine Schmelzpunktanalyse durchgeführt. Sie ermöglicht die Unterscheidung zwischen unspezifischen PCRProdukten wie Primerdimeren mit relativ niedrigen Schmelzpunkten und den erwarteten spezifischen PCR-Produkten mit einem einheitlichen und relativ hohen Schmelzpunkt. 


\section{Durchführung der quantitativen real-time-RT-PCR-Analysen}

Die Expression der zu untersuchenden mRNA-Spezies wurde mit real time RT-PCR nach der Two-Step-RT-PCR-Methode quantifiziert. Bei der Two-Step RT-PCR wird die zuvor transkribierte cDNA in der anschließenden PCR amplifiziert. Der PCRReaktionsansatz enthält eine Hot-Start-DNA-Polymerase. Je Reaktionsansatz wurde nach folgendem Schema auf Eis pipettiert:

iQ Sybr,. Green Supermix

forward Primer $(10 \mathrm{pmol} / \mu \mathrm{l})$

reverse Primer $(10 \mathrm{pmol} / \mu \mathrm{l})$

Fluorescein $^{1}$

Cdna

RNase-freies Wasser
$12,5 \mu \mathrm{l}$

$0,5 \mu \mathrm{l}$

$0,5 \mu \mathrm{l}$

$1 \mu \mathrm{l}$

2,5

ad $25 \mu \mathrm{l}$.

Nach 15 min Inkubation bei $95^{\circ} \mathrm{C}$ erfolgen 40 Zyklen mit $30 \mathrm{~s}$ bei $95^{\circ} \mathrm{C}$ (Denaturierung), $30 \mathrm{~s}$ bei der jeweils angegebenen Anlagerungstemperatur und $30 \mathrm{~s}$ bei $72^{\circ} \mathrm{C}$ (Extension).

Danach wurde eine Schmelzpunktanalyse der RT-PCR-Produkte von $55^{\circ} \mathrm{C}$ bis $95^{\circ} \mathrm{C}$ in $0,5^{\circ} \mathrm{C}$ Schritte zu je 10 Sekunden durchgeführt.

\section{Auswertung}

Die Auswertung erfolgte durch das Programm von BioRad iQ5 Version 2.0 mit der $\Delta \Delta \mathrm{C}_{\mathrm{T}}$-Methode nach Livak und Schmittgen (2001). Dies ermöglicht die relative Quantifizierung der qRT-PCR-Daten, indem die unterschiedliche Expression zweier Proben als $\mathrm{n}$-fache Expression angegeben werden kann. Da die Ausgangsmengen der eingesetzten RNA bzw. cDNA variieren können, ist hierfür ein Referenzgen als interne Kontrolle nötig. Für die Auswertung wurde in diesem Fall als Referenzgen das PBGD gewählt. Die relative Kalibrierung einer Messreihe erfolgt jeweils mit einer unbehandelten Probe, in diesem Fall wurden frisch isolierte Hepatozyten zum Zeitpunkt 0 gewählt und alle anderen Proben als $n$-faches Produkt relativ zu dieser unbehandelten Probe gewertet.

\footnotetext{
${ }^{1}$ fluoreszierender Xanthen-Farbstoff, der zur Kalibration des optischen Systems zugesetzt wird
} 
Die $\Delta \mathrm{C}_{\mathrm{T}}-$ Werte beschreiben die Differenz zwischen dem zu untersuchenden Gen (HO1) und dem Referenzgen (PBGD). Die $\mathrm{C}_{\mathrm{T}}$-Werte des Referenzgens werden von dem zu untersuchenden Gen (HO1) abgezogen und ergeben den $\Delta \mathrm{C}_{\mathrm{T}}-$ Wert.

$$
\Delta \mathrm{C}_{\mathrm{T}}=\mathrm{C}_{\mathrm{T}}(\mathrm{HO1})-\mathrm{C}_{\mathrm{T}}(\mathrm{PBGD})
$$

Der $\Delta \Delta \mathrm{C}_{\mathrm{T}}$-Wert berechnet sich aus der Differenz der $\Delta-\mathrm{C}_{\mathrm{T}}$-Werte jedes beliebig gemessenen Zeitpunktes $\mathrm{x}$ und dem Zeitpunkt 0 des internen Kalibrators.

$$
\Delta \Delta \mathrm{C}_{\mathrm{T}}=\left(\mathrm{C}_{\mathrm{T}(\mathrm{HO1})}-\mathrm{C}_{\mathrm{T}(\mathrm{PBGD})}\right) \text { Zeitpunkt } \mathrm{x}-\left(\mathrm{C}_{\mathrm{T}(\mathrm{HO1})}-\mathrm{C}_{\mathrm{T}(\mathrm{PBGD})}\right) \text { Zeitpunkt } 0
$$

Der $\Delta \Delta \mathrm{C}_{\mathrm{T}}$-Wert ist also das auf den internen Kalibrator normalisierte Verhältnis.

Die Potenzierung des $\Delta \Delta \mathrm{C}_{\mathrm{T}}$-Wertes zur Amplifikationseffizienz als Basis wird üblicherweise mit 2, d. h. Verdopplung des Amplifikates nach jedem Zyklus, angenähert. Damit wird die $\mathrm{n}$-fache Expression der Proben untereinander angegeben.

Für den internen Kalibrator gilt: $\Delta \Delta \mathrm{C}_{\mathrm{T}}=0$ und $2^{0}=1$

Menge des zu untersuchenden Gens $(\mathrm{HO} 1)=2^{-\Delta \Delta} \mathrm{cT}$

\subsection{Bestimmung der NO-Synthase-Aktivität}

Zur Aktivitätsbestimmung wurde den wachsenden Zellen das isotopenmarkierte L[Guanidino- ${ }^{15} \mathrm{~N}_{2}$ ]-Arginin als Substrat in einer Endkonzentration von $5 \mathrm{mM}$ ins Medium gegeben. Das ${ }^{15} \mathrm{~N}_{2}$-Arginin wurde in $0,9 \% \mathrm{NaCl}$ in einer Stammkonzentration von 250 $\mathrm{mM}$ angesetzt $\left(53 \mathrm{mg} / \mathrm{ml}\right.$ ), steril filtriert und bei $4^{\circ} \mathrm{C}$ aufbewahrt. $\mathrm{Zu} 1 \mathrm{ml}$ des Mediums wurden $20 \mu \mathrm{l}$ der Stammlösung zugesetzt. Nach einer Inkubationszeit von $24 \mathrm{~h}$ wurden die durch die NO-Synthase aus ${ }^{15} \mathrm{~N}_{2}$-Arginin gebildeten Mengen an ${ }^{15} \mathrm{~N}$ Nitrit und ${ }^{15} \mathrm{~N}$-Nitrat in $100 \mu \mathrm{l}$ Aliquot-Medium nach erfolgter Derivatisierung der Proben mit Hilfe von Pentafluorobenzylbromid (Tsikas et al. 2000) mittels Gaschromatographie-Massenspektroskopie (GC-MS) gemessen (Tsikas et al. 2000; Tsikas 2004). Die GC-MS-Analysen wurden an dem ThermoElectron DSQ Quadrupol-Massenspektrometer durchgeführt, welcher mit dem Gaschromatographen Focus und dem Autosampler AS 3000 der Firma ThermoElectron (Dreieich, Deutschland) direkt gekoppelt war. Eine Kapillar-Säule Optima-17 (15 m × 0,25 mm i.d., 0,25- $\mu$ m Filmdicke) von Macherey-Nagel (Düren, 
Deutschland) wurde verwendet. Die Quantifizierung erfolgte durch selektierte Detektion der lonen mit einem Masse-zu-Ladungsverhältnis $(\mathrm{m} / \mathrm{z})$ von 46 für ${ }^{14} \mathrm{~N}$ Nitrit, 47 für ${ }^{15} \mathrm{~N}$-Nitrit, 62 für ${ }^{14} \mathrm{~N}$-Nitrat und 63 für ${ }^{15} \mathrm{~N}$-Nitrat mit einer Scanzeit von $50 \mathrm{~ms}$ für jedes lon im Modus der sog. Negative-ion chemical ionization.

Aus den erhaltenen GC-MS-Peaks wurden durch Integration die Peakflächen für alle Ionen berechnet und die Peakflächenverhältnisse $(R)$ von $\mathrm{m} / \mathrm{z} 47 \mathrm{zu} \mathrm{m} / \mathrm{z} 46$ für ${ }^{15} \mathrm{~N}$ Nitrit (R47) und $\mathrm{m} / \mathrm{z} 63 \mathrm{zu} \mathrm{m} / \mathrm{z} 62$ für ${ }^{15} \mathrm{~N}$-Nitrat (R63) gebildet. Aufgrund des Vorkommens des ${ }^{15} \mathrm{~N}$-lsotops mit einer natürlichen und konstanten Häufigkeit von 0,36\% kann ein bestimmter Wert von R47 und R63 nicht unterschritten werden. Die Größe dieser Werte hängt auch vom verwendeten GC-MS-Gerät ab. Typische Werte für das in dieser Arbeit verwendete Gerät und die verwendete Methode sind 0,006 für R47 und 0,007 für R63. Messwerte größer als diese weisen auf die Bildung von ${ }^{15} \mathrm{~N}$ Nitrit bzw. ${ }^{15} \mathrm{~N}$-Nitrat hin. In einem sehr großen Bereich für R47 und R63 besteht eine lineare Beziehung zwischen gebildetem ${ }^{15} \mathrm{~N}$-Nitrit und R47 bzw. gebildetem ${ }^{15} \mathrm{~N}-\mathrm{Nitrat}$ und R63 (Tsikas, 2004). Die Höhe dieser Quotienten ist daher ein quantitatives Maß für die enzymatische Bildung von ${ }^{15} \mathrm{~N}$-Nitrit und ${ }^{15} \mathrm{~N}$-Nitrat aus L-[guanidino $-{ }^{15} \mathrm{~N}_{2}$ ]Arginin und somit ein Maß für die Aktivität der NO-Synthase (Tsikas et al. 2000; Tsikas, 2004).

\subsection{Geräte}

Es wurden folgende Geräte benutzt:

Sterilbank:

„LaminAir Hb 2472“ der Firma Heraeus Instruments, Hannover

Ultrazentrifuge:

"Centrifuge 5804 R“ der Firma Eppendorf, Wesseling-Berzdorf

Zentrifuge: Zentrifuge 5417 der Firma Eppendorf, WesselingBerzdorf

Begasungsbrutschrank: "Cytoperm2“ der Firma Heraeus Instruments, Hannover 
pH-Meter:

Ultraschallgerät:

Photometer: "Sonicator W-220F“ der Firma Heat-Systems, Farmingale, NY, USA

Flüssigkeitsszintillationszähler: „Liquid Scintillation Counter“ der Firma Philips, Straubenhardt

Mikroskop: „Olympus DT5“ der Firma Zeiss, Jena

"iCycler iQ ${ }^{\mathrm{TM}}$ Real-Time

Detection System": der FirmaBio-Rad, München

96-Well-Multiply ${ }^{\circledR}$-PCR-Plate: der Firma Sarstedt, Nümbrecht

Zellkulturschalen (steril): $\quad$ der Firma Nunc GmbH, Wiesbaden

Einmalfilter steril:

der Firma Sartorius, Göttingen

2.11 Chemikalien

Es wurden folgende Chemikalien benutzt:

Williams-E-Pulvermedium (Sonderanfertigung mit 5mM Glucose), EDTA, TCA, BSA, Pulvermedium RPMI, Lactat, Gentamycin

Firma Applichem, Darmstadt

iQ SYBR Green Supermix, iScript cDNA Synthesis Kit

Firma BioRad, München 
Aminoethanol, O-Phosphorylethanolamin, Insulin, Dexamethason, NatriumNitroprussid-Dihydrat, Nicotinamid, Ascorbat-2-Phosphat, EGTA, Natriumselenit, DNase- und RNase-freies Wasser

Firma SIGMA, Taufkirchen

Dimethyl Sulfoxid, Minimum 99,5\% GC

Firma SIGMA, Taufkirchen

L-Cystein Hydrochlorid, Anhydrat

Firma SIGMA, Taufkirchen

CAS 1609, C 93-4845

Firma Aventis Pharma Deutschland, Frankfurt am Main

Tricarbonylchlororuthenium (II) Dimer,

Firma ALDRICH, Steinheim am Albuch

EGF, FGFb, FCS

Firma Biochrom AG, Berlin 


\section{Ergebnisse}

\subsection{Einfluss von Lithiumchlorid auf die Zellteilung und die induzierbare NO-Synthase}

Die Leber ist das einzige Organ im Körper, welches nach einer Teilresektion die Fähigkeit besitzt, ihre Zellen zu replizieren. Leider verlieren die adulten Hepatozyten in Standardkulturmedien die Fähigkeit zu proliferieren. Um die Hepatozyten doch zum Wachstum zu bringen, wurden sie mit einem Spezialmedium zur Proliferation gebracht. Dieses Medium besteht zu 50\% aus einem Grundmedium (GM) mit EGF und FGFb als Wachstumsfaktoren, 20\% Hepatozyten-konditioniertem-Medium (HCM) und 30\% konditioniertem Medium der Leberstromalzellen (SZ-CM).

Das SZ-CM enthält die Mitogene, die den Hepatozyten zur langfristigen Teilung (1-8 Tage) anregen, das HCM führt per se nicht nennenswert zur Zellteilung, fördert jedoch die Wirkung von SZ-CM. Die oben genannte Mischung aus GM, HCM und SZ-CM wird als Komplettmedium (KM) bezeichnet.

\subsubsection{Steigerung der iNOS-Induktion durch Lithiumchlorid}

Esther Wätzig untersuchte 2008 in ihrer Dissertation die Rolle der iNOS in wachsenden kultivierten Hepatozyten. Sie beschrieb, dass die iNOS in proliferierenden Zellen zwar induziert wurde, aber das Wachstum durch Hemmstoffe der iNOS nicht gehemmt werden konnte. Daraus schloss sie, dass die iNOS an der Übermittlung des Wachstumssignals nicht beteiligt ist. Eine sehr starke Induktion der iNOS wurde von Du et al. (2006) nach der Gabe von Lithiumchlorid zu kultivierten, nichtproliferierenden Hepatozyten gezeigt; $\mathrm{LiCl}$ aktiviert über Hemmung der Glykogensynthase-Kinase-3 den Wnt-Weg (Aghdam und Barger 2007). Es stellte sich nun die Frage, ob eine $\mathrm{LiCl}$-abhängige starke Überexpression der iNOS zu einer Aktivierung des Zellwachstums führen kann.

In einem ersten Experiment wurde überprüft, ob in dem hier verwendeten Zellsystem proliferierender Hepatozyten LiCl zur Induktion der iNOS führt. Dazu wurden die Zellen für 10 Tage in Komplettmedium $(\mathrm{KM}) \pm 10 \mathrm{mM} \mathrm{LiCl}$ zur Teilung gebracht und 
die mRNA-Menge der iNOS durch RT-PCR quantifiziert. In frisch isolierten Hepatozyten konnte keine iNOS-mRNA gemessen werden.

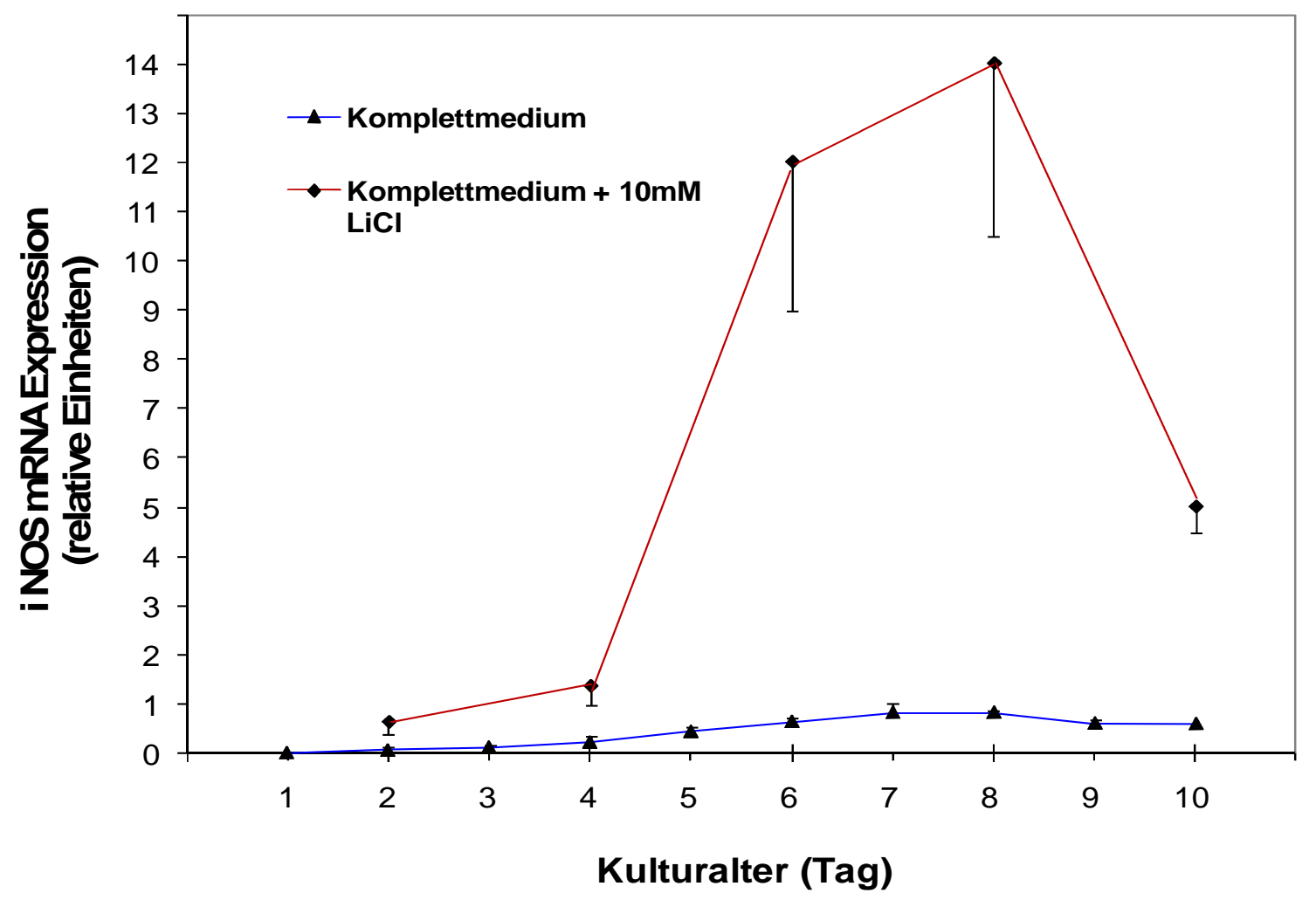

Abb.1: Zeitlicher Verlauf der iNOS- Induktion während des Hepatozytenwachstums.

Die Hepatozyten wurden 10 Tage in Komplettmedium und Komplettmedium mit 10mM LiCl kultiviert. $\mathrm{LiCl}$ wurde täglich zugegeben. Die mRNA wurde durch RT-PCR quantifiziert, die frisch isolierten Hepatozyten enthielten keine Transkripte, der in jedem Einzelversuch höchste Wert der mit Komplettmedium ohne Zusätze kultivierten Zellen wurde auf die relative Einheit 1 gesetzt, alle anderen Werte wurden daran abgeglichen. Die gezeigten Werte sind Mittelwerte \pm SD aus 3 Zellpräparationen, ${ }^{*} \mathrm{p}<0.05, * * \mathrm{p}<0,005$.

In Abwesenheit von LiCl konnte in den ersten drei Tagen keine signifikante Erhöhung des RNA-Gehaltes detektiert werden. Danach stieg der mRNA-Gehalt langsam an und erreichte sein Maximum am 7. Tag. Nach Zugabe von LiCl konnte schon am 2. Tag iNOS-mRNA nachgewiesen werden. Ab dem 4. Tag kam es dann unter dem Einfluss von $\mathrm{LiCl}$ zu einer sehr starken Zunahme der mRNA, welche ihr Maximum zwischen dem 6.-8. Tag erreichte. Die relativen mRNA-Mengen waren gegenüber der Kontrolle ohne LiCl um das 10-15Fache erhöht. Danach nahm der mRNA-Gehalt wieder ab. Mit diesem Versuch zeigen wir, dass in unserem Kultursystem der wachsenden Hepatozyten die iNOS-mRNA Menge durch LiCl sehr stark erhöht wird. 


\subsubsection{Steigerung der iNOS-Aktivität durch Lithiumchlorid}

Zusätzlich zur mRNA-Menge wurde die Enzymaktivität der NO-Synthasen in der Kultur gemessen. Die Hepatozyten bekamen für 24 h 5 mM Arginin, dessen Guanidiniumgruppe das ${ }^{15} \mathrm{~N}$-Isotop enthielt. In den Zellen entstanden dann aus Arginin durch die Aktivität der NO-Synthasen ${ }^{15} \mathrm{NO}$ und ${ }^{14} \mathrm{NO}$, welche weiter $z u{ }^{15} \mathrm{~N}$ Nitrit und ${ }^{14} \mathrm{~N}$-Nitrit reagierten. Der ${ }^{15} \mathrm{~N}$-Nitrit ${ }^{14} \mathrm{~N}$-Nitrit-Quotient und der ${ }^{15} \mathrm{~N}-\mathrm{Nitrat} /{ }^{14} \mathrm{~N}$ Nitrat-Quotient sind somit ein Maß für die Aktivität der NO-Synthase in der lebenden Zelle (Tsikas et al. 2000; Tsikas 2004). Es konnte ein Anstieg der NOS-Aktivität mit einem Aktivitätsmaximum an Tag 6 beobachtet werden (Abb. 2).

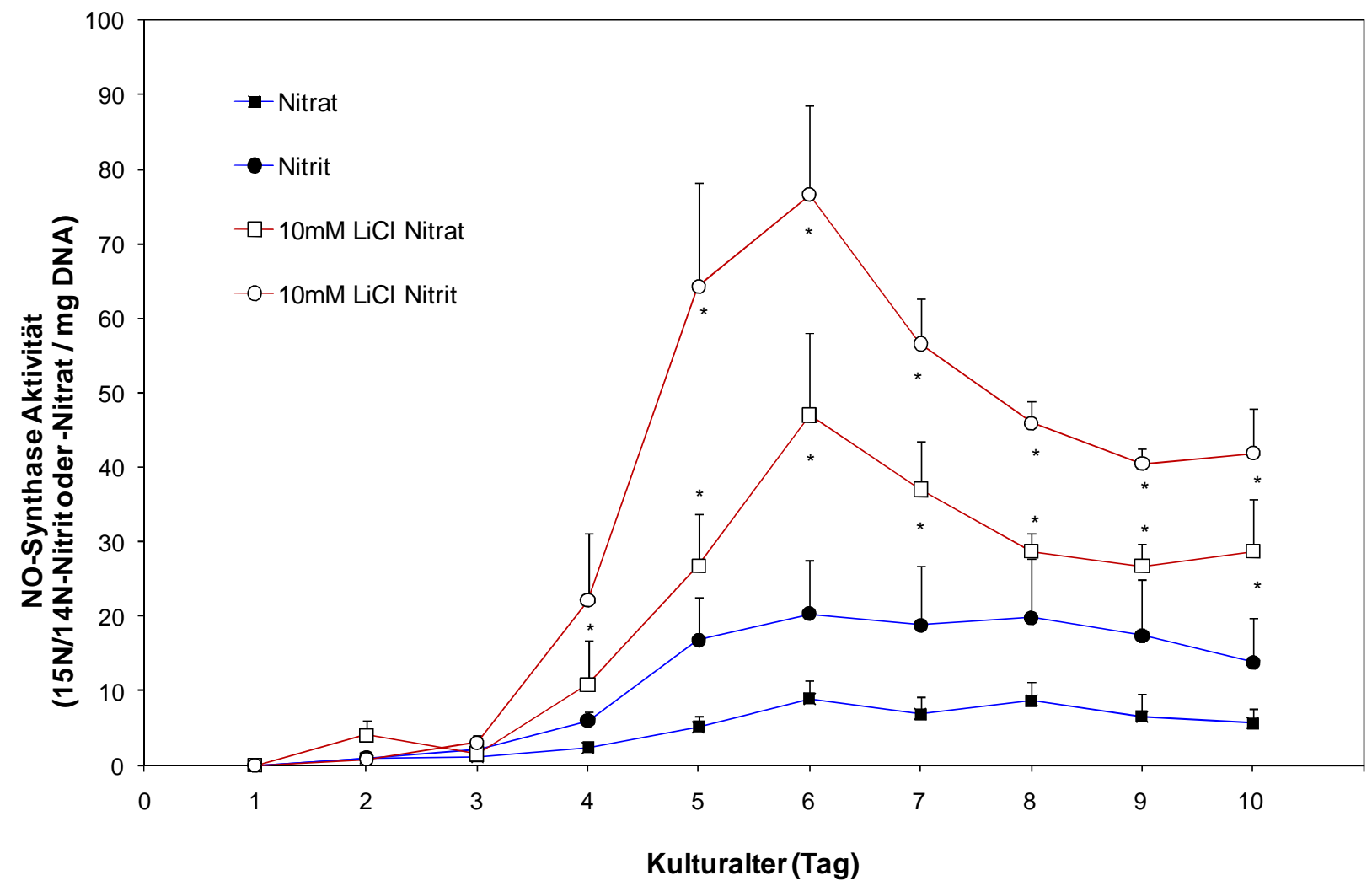

\section{Abb. 2: Die Entwicklung der NO-Synthase-Aktivität im Verlauf des Wachstums kultivierter Rattenhepatozyten.}

Die Hepatozyten wurden für 10 Tage in Komplettmedium $\pm 10 \mathrm{mM} \mathrm{LiCl} \mathrm{kultiviert;} 24 \mathrm{~h}$ vor der Zellernte wurden die Zellen mit $5 \mathrm{mM}{ }^{15} \mathrm{~N}$-Arginin zur Enzymaktivitätsmessung versetzt. Die gezeigten Werte sind Mittelwerte \pm SD aus 3 Zellpräparationen; $*$ p $<0.05$ im Vergleich zu den Werten ohne LiCl. 
Die Kurvenverläufe spiegeln diejenigen der iNOS-mRNA-Menge wider, jedoch erreichte die Aktivitätserhöhung durch $\mathrm{LiCl}$ nicht das Ausmaß der LiCl-stimulierten Erhöhung der mRNA-Menge (vergl. Abb.1). Die Nitrit-Bildung übertrifft die Nitratbildung um $50-100 \%$.

\subsubsection{Wachstumssteigerung durch Lithiumchlorid}

Dieses Experiment wurde durchgeführt, um die Wirkung von $\mathrm{LiCl}$ auf das Wachstum der Hepatozyten zu bestimmen. Dazu wurden die Zellen über 10 Tage in Komplettmedium $\pm 10 \mathrm{mM} \mathrm{LiCl} \mathrm{kultiviert} \mathrm{(Abb.} \mathrm{3).} \mathrm{Des} \mathrm{Weiteren} \mathrm{wurde} \mathrm{in} \mathrm{diesem}$ Experiment auch Interleukin-1ß eingesetzt; dieses Cytokin ist bekannt für seine starke Erhöhung der Induktion der iNOS in kultivierten Rattenhepatozyten (Kitade et al. 1996).

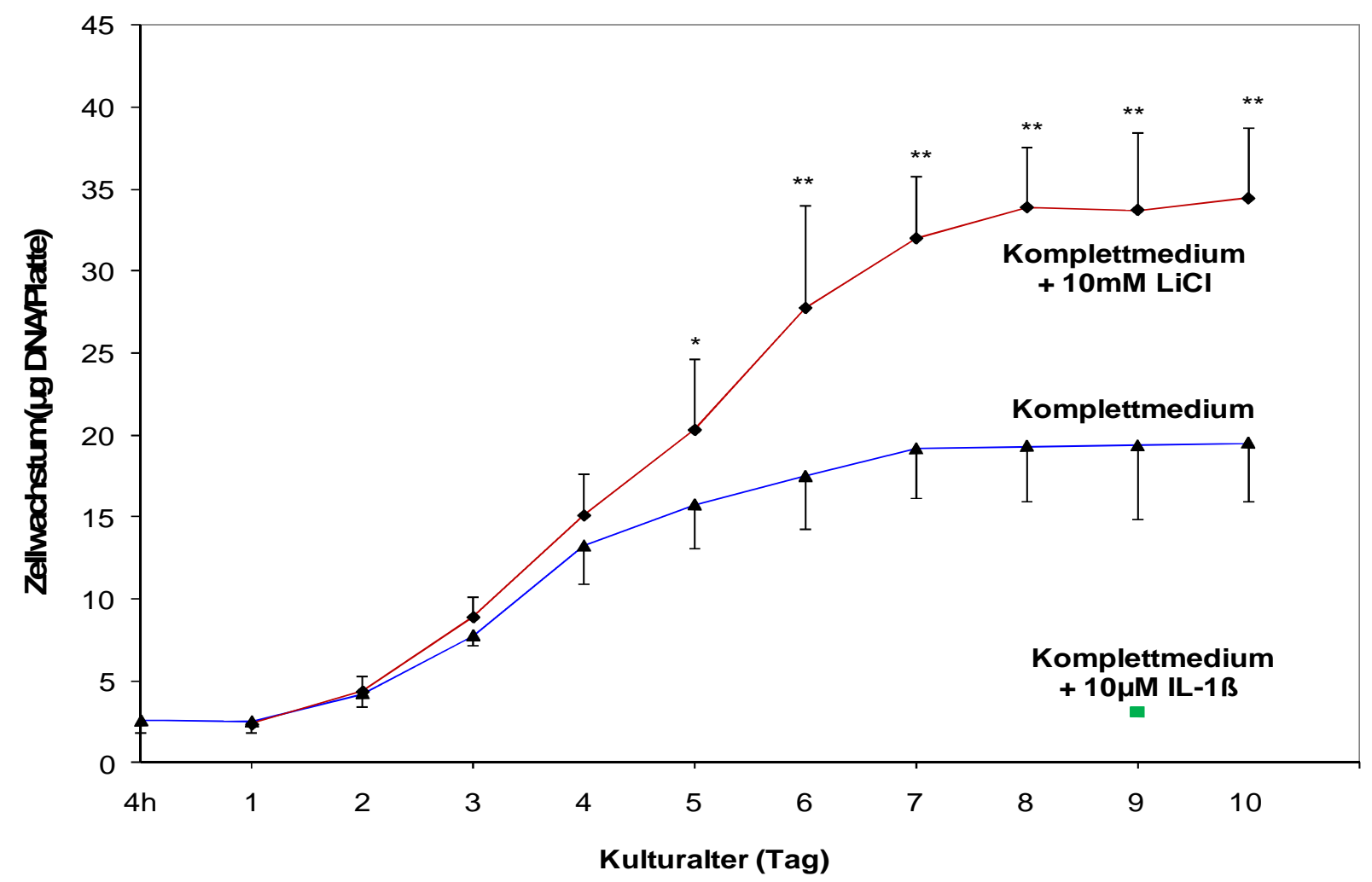

\section{Abb. 3: Einfluss von Lithiumchlorid und Interleukin-1ß auf das Wachstum adulter Hepatozyten in Primärkultur.}

Die Kultivierung der Zellen erfolgte über 10 Tage in Komplettmedium, welches täglich mit $10 \mathrm{mM} \mathrm{LiCl}$ und $20 \mathrm{ng} / \mathrm{ml}$ Interleukin-1ß (IL-1ß) versetzt wurde. Die gezeigten Werte sind Mittelwerte \pm SD aus 3 Zellpräparationen. ${ }^{*} p<0,05, * * p<0,005$ 
Die Zellen zeigten bis zum 4. Tag keinen Unterschied in ihrer Wachstumsrate. Ab dem 4. Tag wuchsen die Zellen in Komplettmedium mit LiCl sehr stark bis zum 7. Tag weiter, wohingegen die Kultur ohne $\mathrm{LiCl}$ ihr Wachstum nach dem 4. Tag deutlich verminderte. Beide Kulturen erreichten die stationäre Wachstumsphase am 7. Tag, die LiCl-behandelten Kulturen wiesen einen um fast das Doppelte erhöhten DNAWert auf. Interleukin-1ß supprimierte das Wachstum vollständig, obwohl es zu einem hohen Anstieg der iNOS-mRNA-Menge und -Aktivität führte (Daten werden nicht gezeigt).

Um herauszufinden, ob es einen kausalen Zusammenhang zwischen iNOSInduktion, NOS-Aktivitätserhöhung und Wachstumserhöhung gibt, wurden in einem nächsten Experiment Hemmstoffe der iNOS-Aktivität eingesetzt. 
Die vorherigen Ergebnisse ließen vermuten, dass die hohe Expression der iNOS durch $\mathrm{LiCl}$ an die durch $\mathrm{LiCl}$ ausgelöste Erhöhung der Hepatozytenproliferation gekoppelt ist. Zur Überprüfung dieser Hypothese wurde untersucht, ob durch den Einsatz von iNOS-spezifischen Hemmstoffen das Hepatozyten-Wachstum und die NOS-Aktivität beeinflusst werden. Dafür wurden die Inhibitoren L-NIL und 1400W eingesetzt (Tabelle 1).

\section{Tabelle 1: Einfluss von iNOS-spezifischen Hemmstoffen auf die NO-Synthase-Aktivität und das Wachstum von Hepatozyten.}

Die Kulturen wurden in Komplettmedium $\pm 10 \mathrm{mM} \mathrm{LiCl} \mathrm{bis} \mathrm{zum} \mathrm{Tag} 6$ kultiviert. Die NOSAktivität wurde über 24 h von Tag 5 auf Tag 6 gemessen. Hemmstoffe wurden täglich neu zugesetzt. Die Daten sind Mittelwerte aus 3. Experimenten.

\begin{tabular}{lcc}
\hline Kultur & $\begin{array}{c}\text { Wachstum } \\
(\mu \mathrm{g} \text { DNA/ Platte })\end{array}$ & $\begin{array}{c}\text { NO-Synthase-Aktivität } \\
\left({ }^{15} \mathrm{~N} /{ }^{14} \mathrm{~N}-\mathrm{Nitrit} / \mathrm{mg} \text { DNA }\right)\end{array}$ \\
\hline $\begin{array}{c}\text { Komplettmedium } \\
+5 \mathrm{mM} \text { L NIL }\end{array}$ & $21,4 \pm 3,1$ & $11,7 \pm 1,10$ \\
$+100 \mu \mathrm{M}$ 1400W & $23,0 \pm 4,0$ & $0,30 \pm 0,02$ \\
& $22,5 \pm 2,5$ & $0,75 \pm 0,05$ \\
Komplettmedium & $33,8 \pm 3,8$ & \\
mit 10mM LiCl & & $46,8 \pm 4,12$ \\
$+5 \mathrm{mM} \mathrm{L} \mathrm{NIL}$ & $37,1 \pm 4,5$ & $1,8 \pm 0,25$ \\
$+100 \mu \mathrm{M} \mathrm{1400W}$ & $32,0 \pm 2,3$ & $3,8 \pm 0,28$ \\
& & \\
\hline
\end{tabular}

Die beiden Inhibitoren führten zu einer sehr starken Hemmung der NOSynthaseaktivität (> 90\%), das Hepatozytenwachstum beeinträchtigten sie jedoch auch in Gegenwart von $\mathrm{LiCl}$ nicht. Das lässt vermuten, dass die Funktion der induzierbaren NO-Synthase nicht direkt für die DNA-Synthese des Hepatozyten 
benötigt wird. Die Zellen proliferierten, obwohl die iNOS-Aktivität fast vollständig gehemmt war.

\subsection{Einfluss des Furoxans CAS 1609 auf Zellteilung und iNOS-Induktion}

In vielen Publikationen wurde beschrieben, dass NO eine wichtige Rolle bei der Regeneration der Leber spielt. Dies muss jedoch für isolierte Hepatozyten in Reinkultur bezweifelt werden, da sowohl Esther Wätzig in ihrer Dissertation (2008) als auch wir im oben vorgestellten Versuch (Tabelle 1) gezeigt haben, dass die iNOS-Aktivität für das Wachstum unter unseren Kulturbedingungen nicht essentiell ist. Wätzig untersuchte auch die mitogene Wirkung von sieben NO-Donatoren; als einziger der getesteten Donatoren stimulierte das Furoxan CAS 1609 das Wachstum.

In den folgenden zwei Versuchen wurde untersucht, wie CAS $1609 \mathrm{im}$ Vergleich zu $\mathrm{LiCl}$ das Wachstum und die Menge der iNOS-mRNA beeinflusst.

In der Abbildung 4 wird die Kultivierung der Zellen über 10 Tage in Komplettmedium $\pm 10 \mathrm{mM} \mathrm{LiCl}$ und $\pm 100 \mu \mathrm{M}$ CAS 1609 dargestellt. Die Hepatozyten zeigten bis zum 4. Tag in ihrem Wachstum keine Veränderung durch die zwei Zusätze. Ab dem 4. Tag wurde das Zellwachstum durch beide Zusätze deutlich beschleunigt. Unabhängig von LiCl oder CAS 1609 erreichen alle drei Kulturen die stationäre Wachstumsphase am 7. Tag. Die Kulturen, die mit LiCl behandelt wurden, wiesen einen zur Kontrolle um fast das Doppelte erhöhten DNA-Wert ( $\mu \mathrm{g} /$ Platte) auf; die mit CAS 1609 behandelten Platten zeigten einen um 35\% erhöhten DNA-Wert im Vergleich zu den Kontrollplatten. 


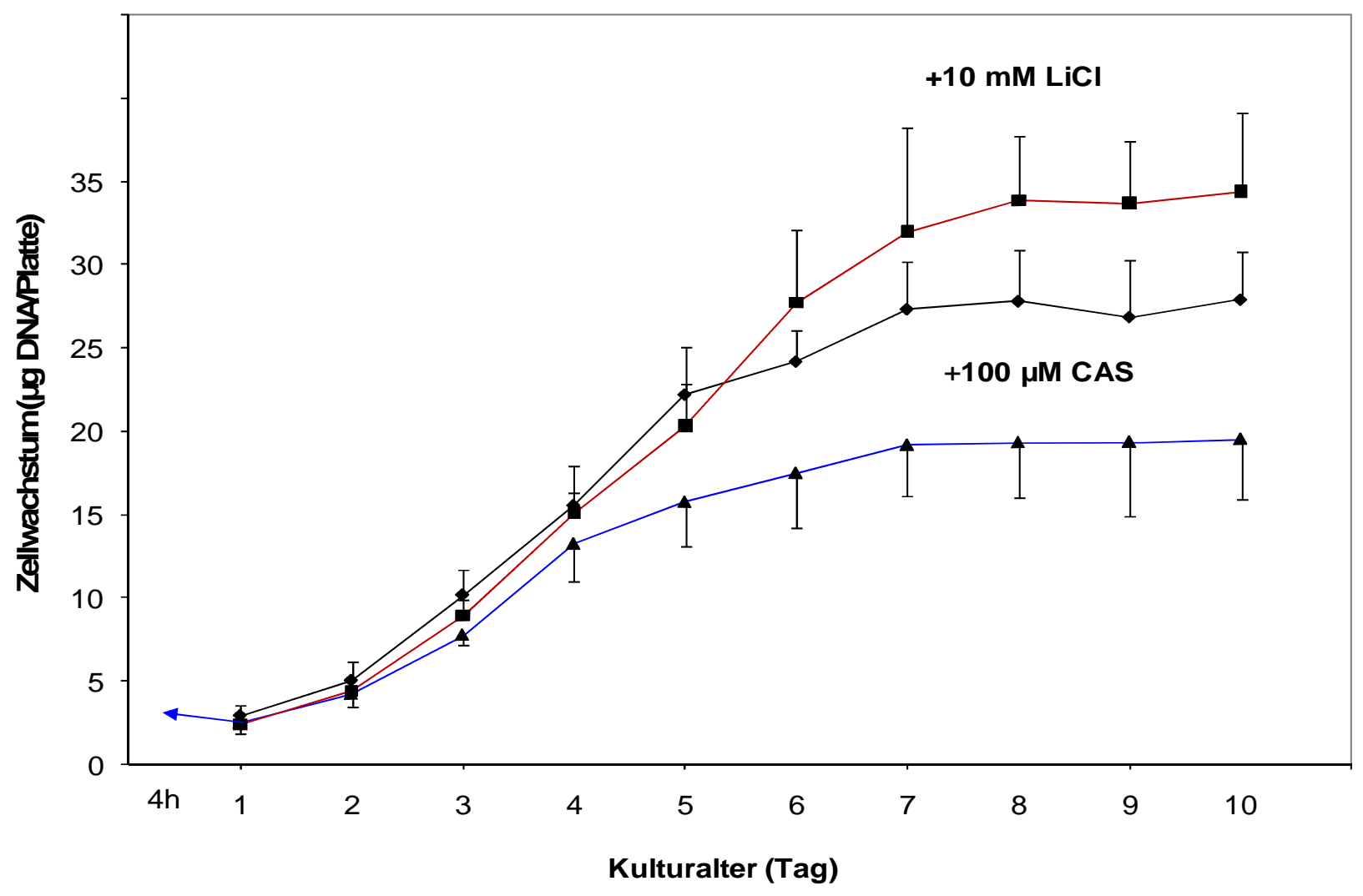

\section{Abb.4: Einfluss von CAS 1609 und Lithiumchlorid auf das Wachstum adulter Hepatozyten.}

Die Zellen wurden für 10 Tage in Komplettmedium, welches ab dem 1.Mediumwechsel nach 4h mit 4-Hydroxymethyl-Furoxan-3-Carboxyamid (CAS 1609) und Lithiumchlorid (LiCl) versetzt wurde, kultiviert. Die gezeigten Werte sind Mittelwerte \pm SD aus 3 Zellpräparationen.

In einem weiteren Versuch wurde die Wirkung von CAS 1609 auf die Induktion der iNOS unter Wachstumsbedingungen überprüft. Dafür wurden die Kulturen für 10 Tage in Komplettmedium $\pm 10 \mathrm{mM} \mathrm{LiCl}$ und $\pm 100 \mu \mathrm{M}$ CAS 1609 kultiviert und die mRNA-Menge der iNOS durch RT-PCR quantifiziert (Abb.5). In frisch isolierten Hepatozyten konnte keine iNOS-mRNA gemessen werden. Jeden 2. Tag wurden die Zellen zur Messung geerntet.

In Gegenwart von CAS 1609 wurde die Induktion der iNOS drastisch gehemmt: wuchsen die Zellen ohne LiCl, so hemmte CAS 1609 die Induktion bis zum Tag 6 um $>90 \%$, danach ließ die Hemmwirkung etwas nach und die mRNA-Menge stieg auf ca. $20 \%$ der Menge in Kontrollzellen an. In Gegenwart von LiCl, welches wie in Abb.1 
gezeigt zu einer sehr hohen iNOS-Induktion führte, konnte CAS 1609 seine hemmende Wirkung noch stärker, fast unvermindert bis zum Kulturende ausüben.

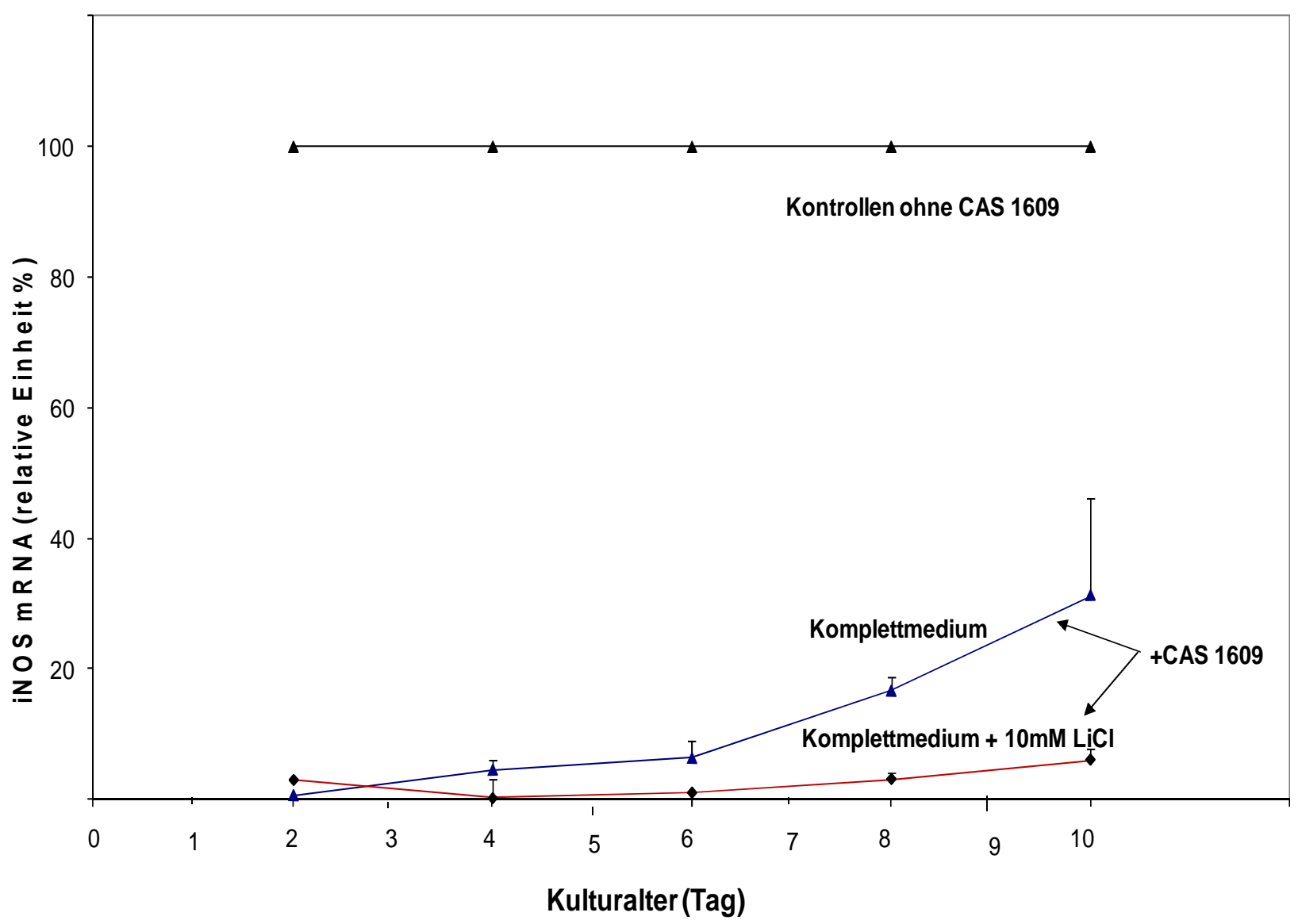

Abb.5: Hemmung der iNOS-Induktion durch CAS 1609.

Die Hepatozyten wurden für 10 Tage in Komplettmedium mit $\pm 10 \mathrm{mM} \mathrm{LiCl}$ und $\pm 100 \mu \mathrm{M} 4$ Hydroxymethyl-Furoxan-3-Carboxyamid (CAS1609) kultiviert. Die mRNA der iNOS wurde durch RT-PCR quantifiziert, die frisch isolierten Hepatozyten enthielten keine Transkripte, der in jedem Einzelversuch höchste Wert der mit Komplettmedium $\pm 10 \mathrm{mM} \mathrm{LiCl}$ kultivierten Zellen wurde auf die relative Einheit 100\% gesetzt, alle anderen Werte daran abgeglichen. Die gezeigten Werte sind Mittelwerte \pm SD aus 3 Zellpräparationen. 


\subsection{Induktion der Hämoxygenase-1 durch CAS 1609}

Das zweite Gas, dessen mitogener Effekt in dieser Arbeit untersucht wurde, war Kohlenmonoxid (CO).

$\mathrm{CO}$ ist eines der Endprodukte der Hämoxygenase-1-Reaktion und zeigt ähnliche Eigenschaften wie $\mathrm{NO}$ in Bezug auf Apoptoseprotektion nach einer Leberteilresektion. Beide Gase sind in der Lage, sich gegenseitig zu beeinflussen. Ihr Zusammenspiel fördert die ausreichende Durchblutung und reduziert die Scherkräfte nach der Leberteilresektion (Schuett et al. 2007). Des Weiteren kann NO die Hämoxygenase-1 (HO-1) induzieren (Kim YM et al. 1995).

Es stellte sich daher die Frage, ob CAS 1609 über die Induktion der HO-1 mitogen wirkt. Experimente zu dieser Frage wurden in GM/HCM-Medium durchgeführt, da Wätzig 2008 unter diesen Bedingungen einen besonders hohen mitogenen Effekt von CAS 1609 gezeigt hatte. Um das Kultursystem in dieser Hinsicht noch einmal zu überprüfen, wurde in einem Vorexperiment der Einfluss von CAS 1609 in GM/HCMMedium auf das Wachstum gemessen, wobei die erste Gabe von CAS 1609 entweder sofort nach $4 \mathrm{~h}$ oder erst nach $48 \mathrm{~h}$ Kulturdauer erfolgte (Abb. 6).

Unterschiede in der Wachstumsgeschwindigkeit wurden erst nach dem 2. Tag deutlich. Ab dem 4. Tag wurde das Zellwachstum durch CAS 1609 deutlich beschleunigt. Unabhängig vom Zeitpunkt der 1. Zugabe von CAS 1609 erreichen alle Kulturen die stationäre Wachstumsphase am 7. Tag. Die Kulturen, die CAS 1609 bereits nach 4 Stunden erhielten, wiesen nach 7 Tagen einen zur Kontrolle (GM/HCM) um fast das Dreifache erhöhten DNA-Wert ( $\mu \mathrm{g} / \mathrm{Platte}$ ) auf; die Kulturen welche CAS 1609 erst nach 2 Tagen erhielten, zeigten einen um fast das Doppelte erhöhten DNA-Wert im Vergleich zu den Kontrollplatten auf. Beide mit CAS 1609 stimulierten Kulturen zeigten ein langsameres Wachstum als in Komplettmedium aufgezogene Kulturen. 


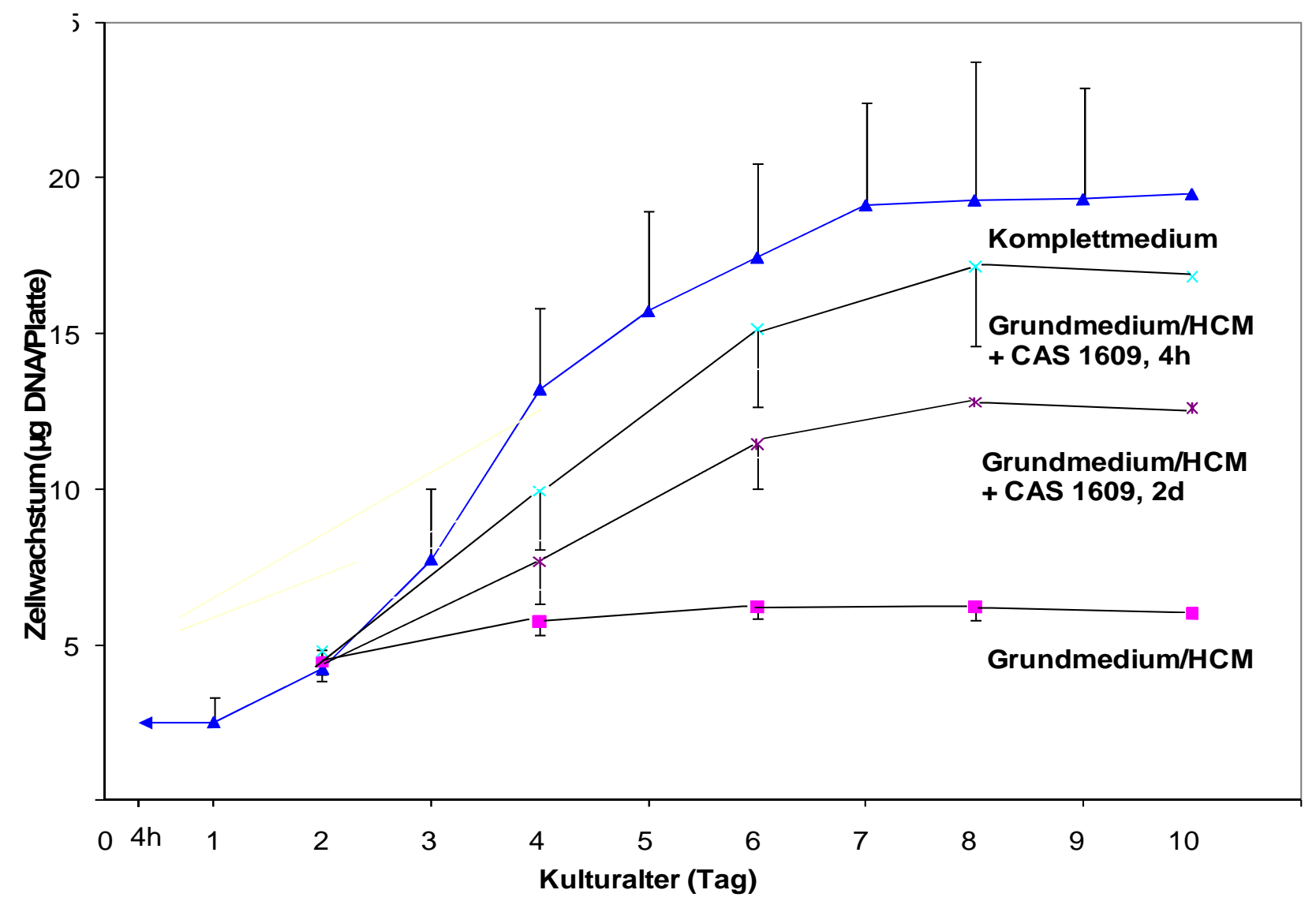

Abb. 6: Zeitlicher Verlauf von Hepatozyten unter Einfluss von CAS 1609 in Primärkultur.

Die Kultivierung der Zellen erfolgte über 10 Tage in Komplettmedium und Grundmedium mit HCM 20\%, welches zum Zeitpunkt 4 oder 48 Stunden (1. Mediumwechsel) mit 100 $\mu$ M CAS 1609 versetzt wurde. Die gezeigten Werte sind Mittelwerte \pm SD aus 3 Zellpräparationen.

Das Furoxan CAS 1609, welches eine proliferationssteigernde Wirkung hat, führte also zu einer Erhöhung des Zellwachstums. Die Induktion der HO-1 wurde unter identischen Bedingungen zum vorherigen Experiment (Abb. 6) durchgeführt, die erste Gabe von CAS 1609 erfolgte entweder nach 4 h oder nach 48 h Kulturdauer (Abb. 7). 


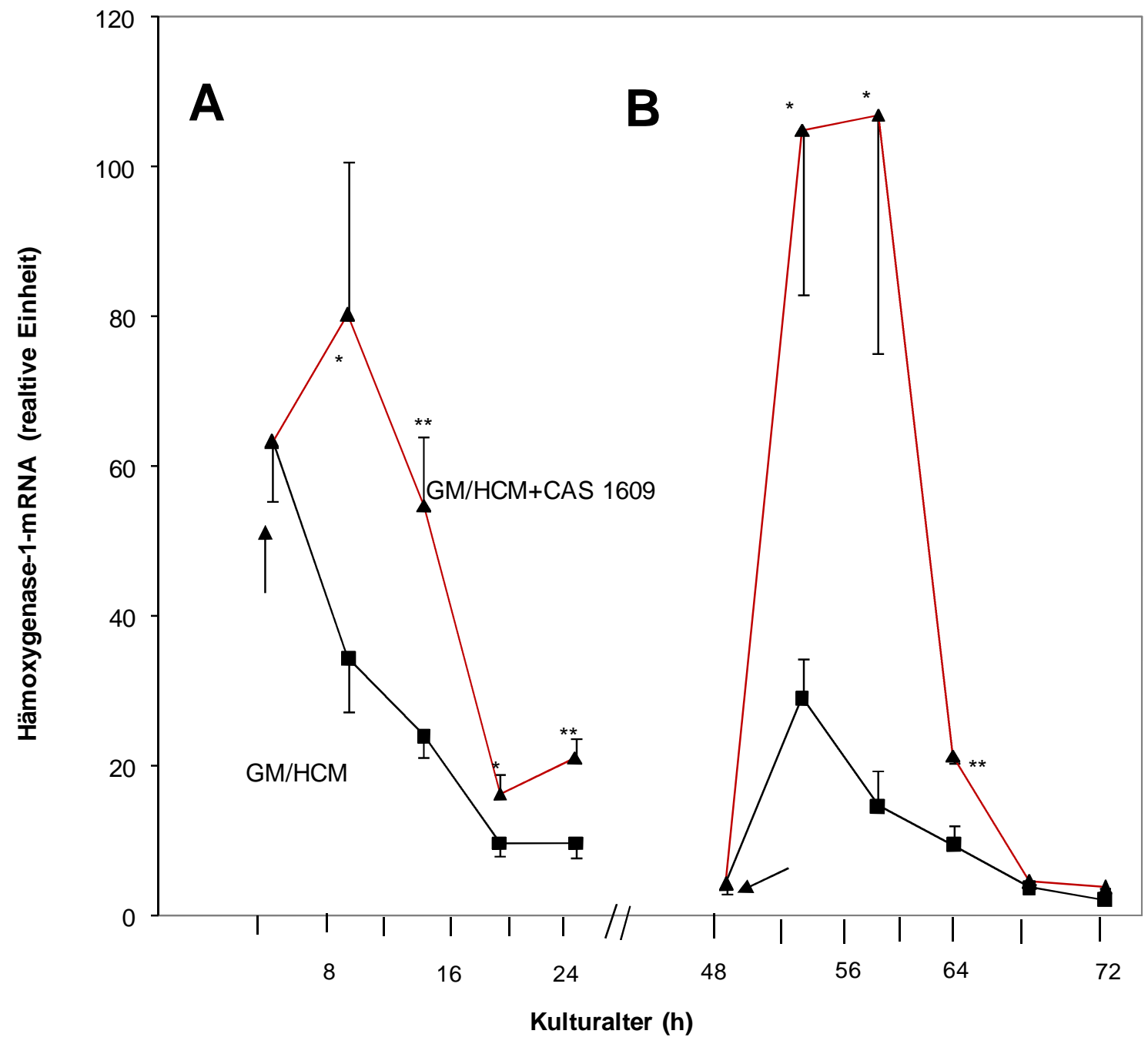

Abb. 7: Zeitlicher Verlauf der Hämoxygenase-1-mRNA-Expression.

Die Hepatozyten wurden in Grundmedium mit 20\% HCM kultiviert.

Beim ersten Mediumwechsel nach $4 \mathrm{~h}$ (A) oder nach $48 \mathrm{~h}$ (B) wurden 100 $\mu \mathrm{M} 4$ -

Hydroxymethyl-Furoxan-3-Carboxamid (CAS 1609) hinzugefügt. Die mRNA der HO-1 wurde durch RT-PCR quantifiziert, die frisch isolierten Hepatozyten enthielten keine Transkripte, der in jedem Einzelversuch höchste Wert der mit Grundmedium ohne Zusätze kultivierten Zellen wurde auf die relative Einheit 1 gesetzt, alle anderen Werte daran abgeglichen. Die gezeigten Werte sind Mittelwerte \pm SD von sechs (A) und drei (B) Zellpräparationen $* \mathrm{P}<0,05$, $* * \mathrm{p}<0,005$.

Die mRNA der HO-1 wurde durch RT-PCR quantifiziert, die frisch isolierten Hepatozyten enthielten keine Transkripte. Die sehr kleine Menge an HO-1-mRNA in frisch isolierten, nicht plattierten Zellen (deren Wert auf die relative Einheit 1 gesetzt wurde) stieg während der 4-stündigen Anheftungszeit der Zellen um das 60Fache 
an, fiel danach steil ab und erreichte nach weiteren 16 Stunden einen um das 10Fache erhöhten konstanten Spiegel (Abb. 7A). Dieser transiente Anstieg ist auf den Schock zurückzuführen, den die Zellen durch die Isolierung aus dem Gewebeverband erlitten hatten. Nach jedem Mediumwechsel (Abb. 7B, neues Medium zum Zeitpunkt $48 \mathrm{~h}$ ) wiederholte sich dieser transiente mRNA-Anstieg, allerdings in stark abgeschwächter Form. Wurde CAS 1609 nach dem Mediumwechsel zum Zeitpunkt $4 \mathrm{~h}$ zugegeben (Abb. 7A), so verzögerte sich der Rückgang der mRNA-Menge sehr deutlich. Der Induktionseffekt von CAS 1609 wurde ausgezeichnet sichtbar, wenn die allererste Gabe des Furoxans erst nach 48 h erfolgte, zu einem Zeitpunkt, an dem die Zellen den Isolierungsstress überwunden hatten; CAS 1609 führte unter diesen Bedingungen (Abb. 7B) zu einem 20-30-fachen Anstieg der HO-1-mRNA.

3.4. Wirkung des CO-Donators Tricarbonylchlororuthenium(II)-Dimer (CORM 2) auf das Hepatozytenwachstum

Die funktionelle Bedeutung des Anstieges der HO-1-mRNA durch CAS 1609 für das Zellwachstum wurde durch den Einsatz des CO-Donators CORM 2 überprüft. Tatsächlich stimulierte CORM 2 die Proliferation der Zellen im gleichen Ausmaß wie CAS 1609 dies bewirkte (Abb. 8). Der maximale Effekt wurde mit $20 \mu \mathrm{M}$ CORM 2 erzielt. Es stellte sich heraus, dass die bei höheren CORM 2-Konzentrationen auftretenden Zellschädigungen zum großen Teil unterdrückt wurden, wenn die CORM 2-Menge auf 2 Gaben (morgens und abends) verteilt wurde. 


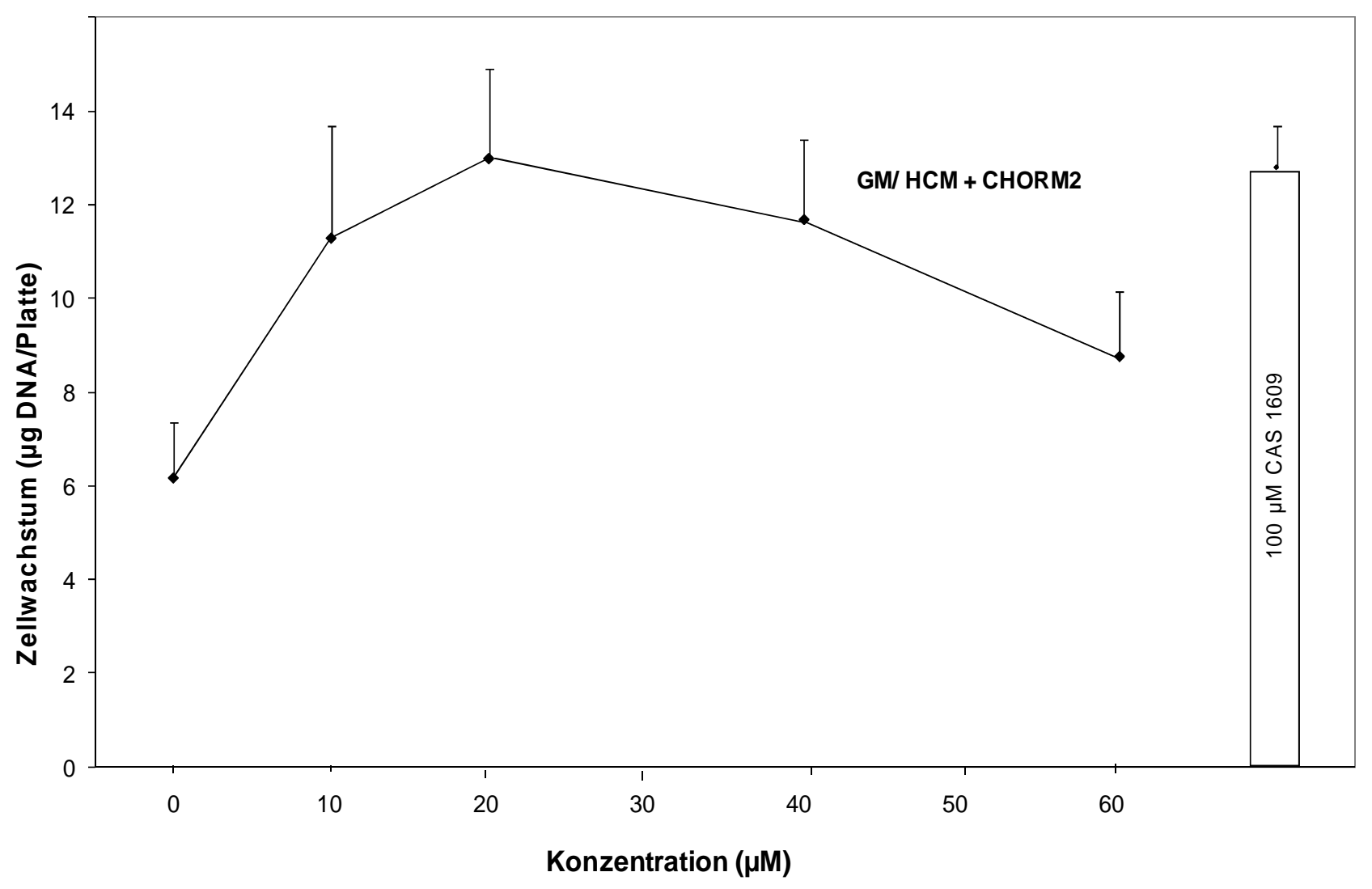

\section{Abb. 8: Mitogene Wirkung von CORM 2 auf das Wachstum der Rattenhepatozyten. Dosis-Wirkungskurve.}

Die Zellen wurden täglich zweimal (8 und 20 Uhr) mit der Hälfte der angegebenen Dosis von CORM 2 versetzt. Die Zellen wurden in GM/HCM kultiviert. An Tag 6 wurden die Zellen zur DNA-Bestimmung geerntet. Die gezeigten Werte sind Mittelwerte \pm SD aus 3

Zellpräparationen. 


\subsection{Aufbau einer Kultur proliferierender Hepatozyten aus der adulten Maus}

Eine weitere Aufgabe dieser Arbeit bestand darin, adulte Maushepatozyten serumfrei in vitro zur Proliferation zu bringen. Dazu wurde im Wesentlichen das Protokoll, welches für die Proliferation adulter Rattenhepatozyten ausgearbeitet worden war (Koenig et al. 2006), verwendet.

Es war zunächst zu prüfen, welche Art der Kollagenbeschichtung der Kulturplatte ein rasches Wachstum ermöglichte. Um diese Frage zu beantworten, wurde das Experiment wie folgt durchgeführt.

Die Maushepatozyten wurden nach der Isolierung und Aufbereitung für 6 Tage in Grundmedium oder in Komplettmedium $\pm 10 \mathrm{mM} \mathrm{LiCl}$ kultiviert (30000 Zellen pro 3,5 cm Platte). Als Biomatrix wurde natives oder Glutaraldehyd-quervernetzes Kollagen verwendet. Der Kollagenuntergrund wurde entweder als flexibles dreidimensionales Gel angeboten oder vor der Beschichtung mit Hepatozyten für 2 Tage unter der laufenden Impfbank eingetrocknet. Am 6. Tag wurden alle Platten geerntet und die DNA quantifiziert.

Im Gegensatz zu Rattenhepatozyten benötigten die Maushepatozyten zum Wachstum in Komplettmedium (KM) quervernetztes und dadurch nicht abbaubares Kollagen; dieser Untergrund musste als Gelmatrix aufgebracht werden (Abb.9).

$\mathrm{LiCl}$ erhöhte das Wachstum zusätzlich; durch die Zugabe von $\mathrm{LiCl}$ in $\mathrm{KM}$ proliferierten die Hepatozyten um das Vierfache und ohne $\mathrm{LiCl}$ um das Dreifache, verglichen mit dem Wachstum in GM.

Die eingetrockneten Kollagenuntergründe unterstützten das Wachstum nur geringfügig, die Zellen verloren ihre kompakte Form und zeigten eine fibroblastenähnliche Morphologie. Das native Kollagen wurde zudem schon in den ersten 3 Tagen massiv abgebaut, was zu einem Verlust der Zelladhärenz führte. Es war von Vorteil die Maushepatozyten mit einer geringeren Dichte (30.000 Zellen pro $\varnothing$ 3,5-cm-Platte im Vergleich zu 50.000 für Rattenhepatozyten) auszuplattieren. Die Maushepatozyten zeigten bei geringerer Dichte höheres Wachstum. 


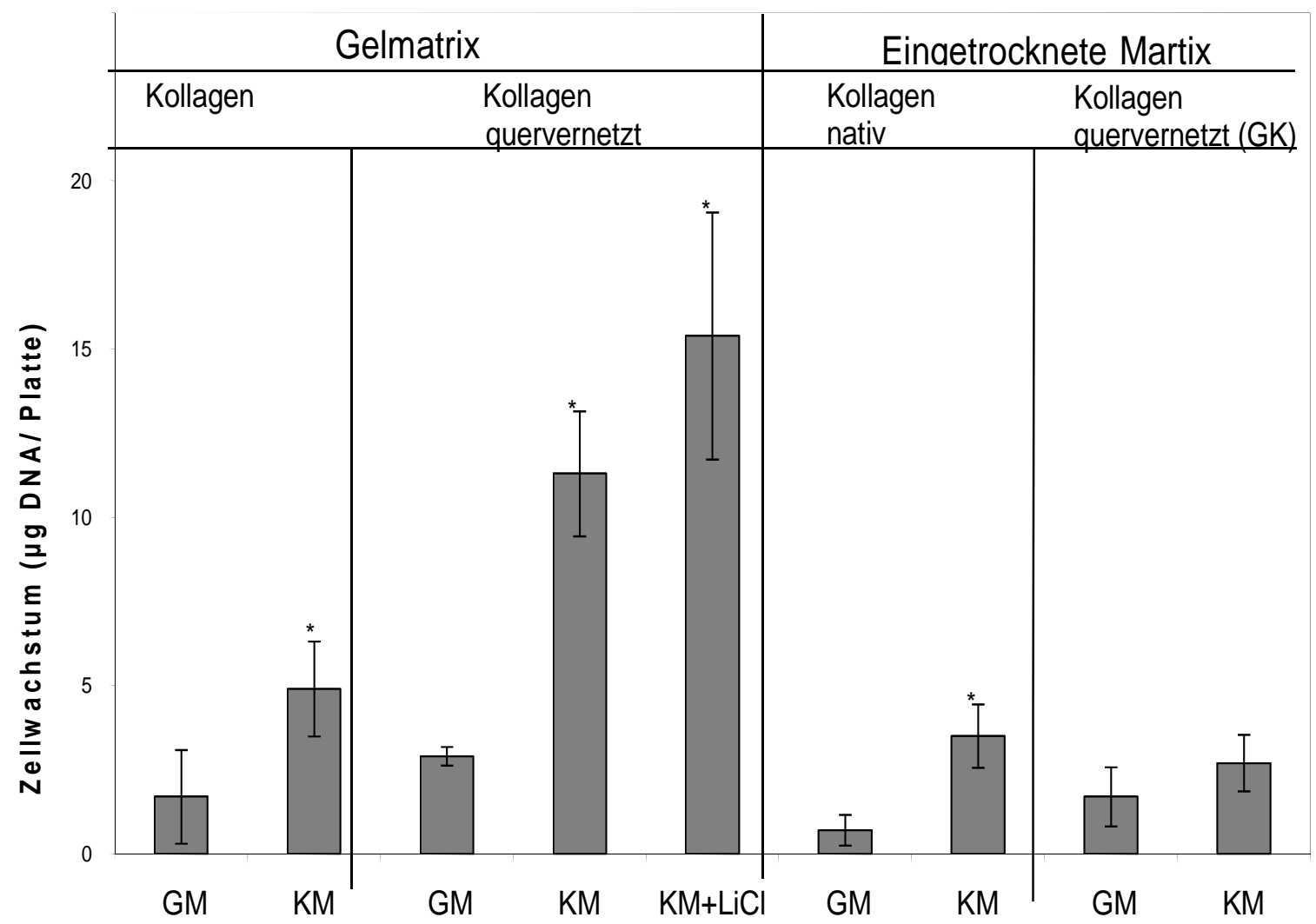

\section{Abb. 9: Einfluss der Biomatrix (Plattenbeschichtung) und der Medienzusammensetzung auf das Wachstum der Maushepatozyten.}

Die Maushepatozyten wurden entweder in Grundmedium (GM), Komplettmedium (KM) oder KM mit 10mM Lithiumchlorid ( $\mathrm{LiCl}$ ) für 6 Tage kultiviert. Der Plattenboden wurde mit nativem oder mit Glutaraldehyd-quervernetztem Kollagen Typ1 beschichtet und das Kollagen für 2 Tage auf dem Plattenboden getrocknet (eingetrocknete Matrix). Die beweglichen schwammartigen Kollagengele wurden wie im Methodenteil beschrieben, auf die Plattenböden aufgebracht. Die gezeigten Werte sind Mittelwerte \pm SD aus 3 Zellpräparationen. ${ }^{*} \mathrm{p}<0,05$

In einem weiteren Versuch wurde das zeitliche Wachstumsverhalten der Zellen untersucht. Die Hepatozyten wurden über 10 Tage in Grundmedium, Komplettmedium und Komplettmedium mit $10 \mathrm{mM} \mathrm{LiCl}$ kultiviert. Die konditionierten Medien (HCM und SZ-CM) wurden von Rattenleberzellen und nicht von Mausleberzellen gewonnen. Als Matrix wurden quervernetzte Kollagengele verwendet.

Die Zellen zeigten in Grundmedium, dem die konditionierten Medien fehlen, ein sehr geringes Wachstum (Abb.10). Dieses Wachstum konnte durch Komplettmedium um 
das 5Fache gesteigert werden. Der Zusatz von LiCl steigerte das Wachstum um das 8Fache; jedoch setzte der Effekt von $\mathrm{LiCl}$ erst nach 4 Tagen ein. Dieses Wachstumsverhalten entspricht dem der Rattenhepatozyten. Im Gegensatz zu der Rattenhepatozytenkultur zeigten die Maushepatozyten inr Poliferationsmaximum bereits an Tag 4 und stellten inr Wachstum ab Tag 6 nach Erreichen der Konfluenz ein.

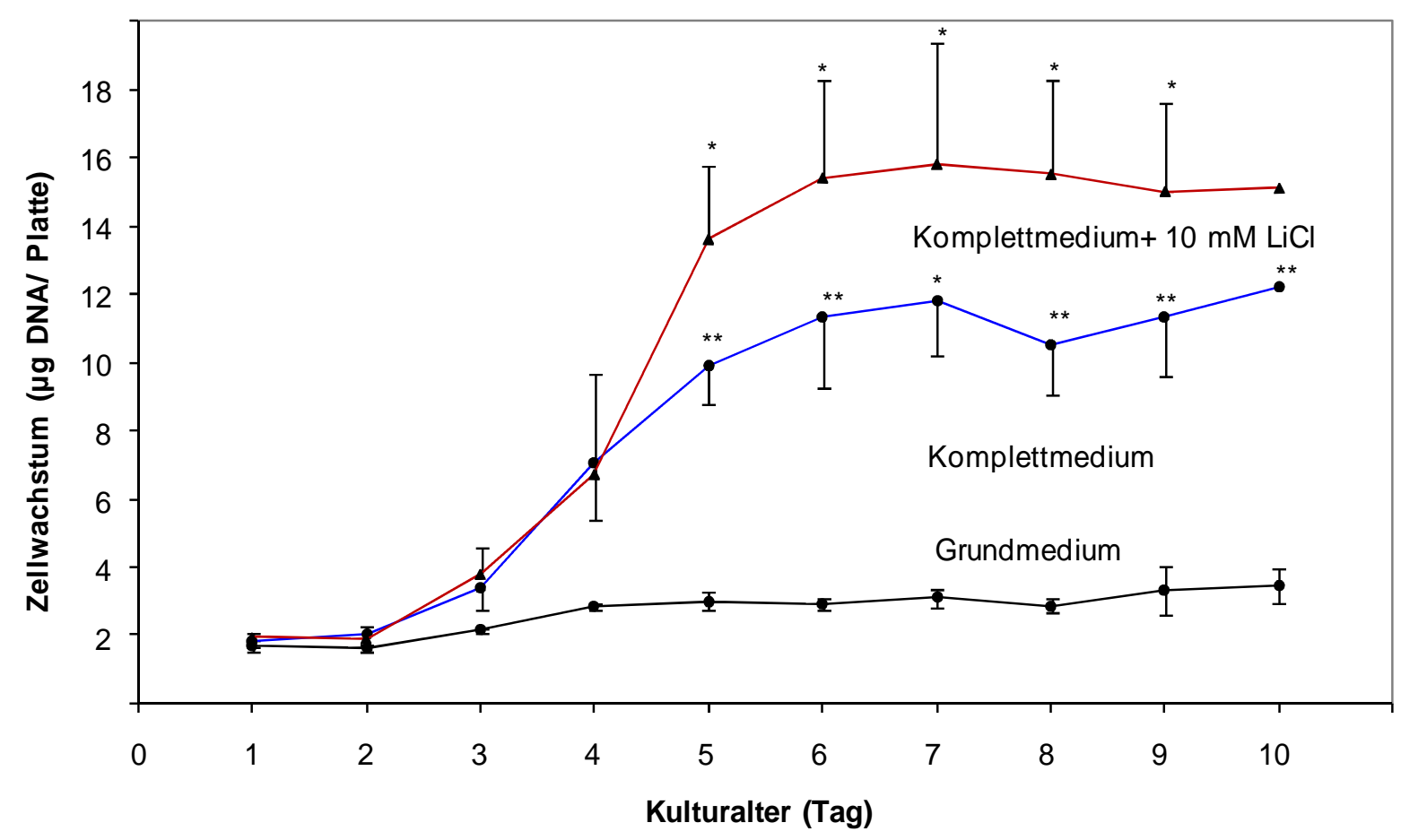

Abb. 10: Einfluss von Lithiumchlorid auf das Wachstum von adulten Maushepatozyten.

Die Hepatozyten wurden über 10 Tage in Grundmedium, Komplettmedium und Komplettmedium mit 10mM Lithiumchlorid ( $\mathrm{LiCl}$ ) kultiviert. Als Matrix wurden quervernetzte Kollagengele verwendet. Die gezeigten Werte sind Mittelwerte \pm SD aus 3 Zellpräparationen. $* \mathrm{p}<0,05, * * \mathrm{p}<0,005$

Diese Ergebnisse zeigen, dass das für Rattenhepatozyten ausgearbeitete MedienProtokoll für die Proliferation von Maushepatozyten benutzt werden kann. Der Unterschied in der Ratten- und Maushepatozyten-Kultur ist die Verwendung einer unterschiedlichen Gel-Biomatrix, natives Kollagen für die Rattenhepatozyten und Glutaraldehyd-quervernetztes Kollagen für die Maushepatozyten. Um das unterschiedliche Wachstum der Maushepatozyten deutlich zu zeigen, wurden 
lichtmikroskopische Aufnahmen vom 2. bis 8. Tag gemacht (Abb.11). Bis zum 2. Tag sah man bei den Kulturen kaum einen Unterschied. Am 4. Tag waren vermehrt Hepatozyten-Kolonien in Komplettmedium $\pm \mathrm{LiCl}$, während in Grundmedium kultivierte Zellen nur leicht proliferierten. Am 8. Tag sah man sehr große Zellkolonien in Komplettmedium mit $\mathrm{LiCl}$ kultivierten Platten und kleine Zellkolonien in Grundmedium. 

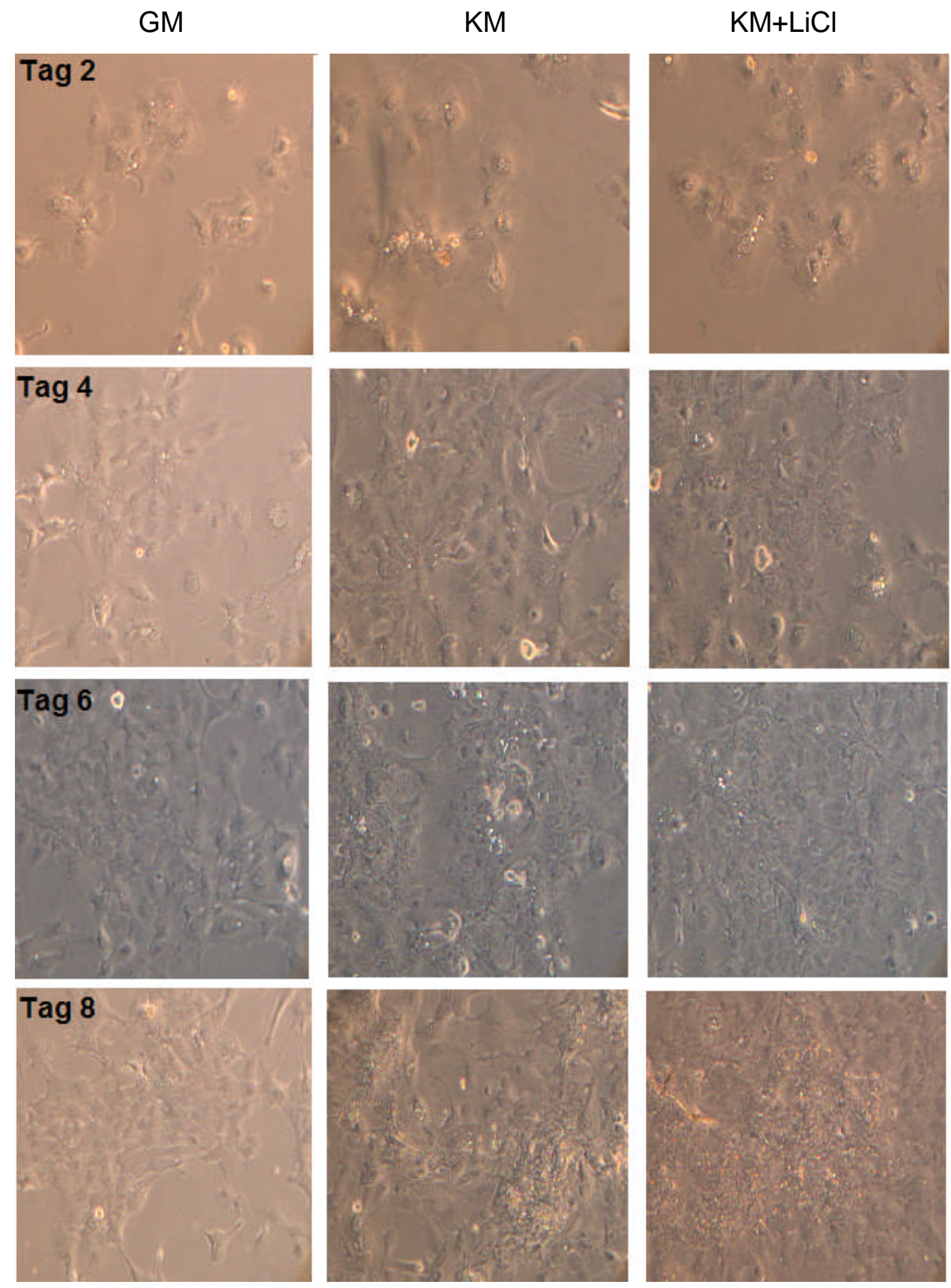

\section{Abb.11: Lichtmikroskopische Aufnahmen kultivierter Maushepatozyten.}

Die Zellen wurden mit Grundmedium, Komplettmedium und Komplettmedium mit $10 \mu \mathrm{M}$ LiCl kultiviert. Als Biomatrix wurde bei allen Platten Glutaraldehyd-quervernetztes Kollagen verwendet. An jedem 2. Tag wurde eine Aufnahme gemacht. 


\section{Diskussion}

Das Enzym NO-Synthase (NOS) produziert $\mathrm{NO}$ aus L-Arginin unter $\mathrm{O}_{2}$-Reduktion.in der Leber werden die bekannten 4 Isoformen exprimiert: Die neuronale NOS wird in den Hepatozyten während der Leberzirrhose und in immunopositiven Nervenendfasern exprimiert (Wei et al. 2002; Esteban et al. 1997). Die endotheliale NOS wird über die gesamten Hepatozyten der Leber, im Endothel von Leberarterien, Lebervenen, Gallengängen und Sinusoiden gebildet (McNaughton et al. 2002). Die Funktion der konstitutiv exprimierten eNOS ist die der Aufrechterhaltung der Mikrozirkulation in der Leber (Chen et al. 2003). Die mitochondriale NOS, eine Isoform der neuronalen NOS, reguliert den mitochondrialen $\mathrm{O}_{2}$-Verbrauch durch reversible Bildung an die Cytochrom c Oxidase (Giulivi et al. 2006).

Die induzierbare NOS wird von Hepatozyten, Makrophagen und glatten Muskelzellen gebildet (Harbrecht und Billiar 1995). Die Expression der iNOS wird während leberschädigender Prozesse wie Cholestase, Hepatitis und Zirrhose (Farzaneh-Far und Moore 2001, Farghali et al. 2002 und Chen et al. 2003) von Zytokinen und Endotoxinen gesteuert. Das Enzym wird induziert durch Interleukin-6 (IL-6), Tumornekrosefaktor- $\alpha$ (TNF $\alpha)$ und Interleukin-1 $\beta$ (IL-1 $\beta$ ) (Nüssler et al. 1993).

In der Literatur wird die Rolle des Stickstoffmonoxids bei der Leberregeneration widersprüchlich dargestellt. Wir unterscheiden die Ergebnisse zwischen in-vitro- und in-vivo-Experimenten.

\subsection{Einfluss von NO auf die Leberregeneration in vivo}

Wir werden zuerst schauen, wie das Molekül NO und das Enzym iNOS die Leber im lebenden Organismus nach der Leberteilresektion beeinflussen. Die beiden Arbeitsgruppen von Rai et al. (1998) und Zeini et al. (2005) experimentierten mit iNOS-knockout-Mäusen. Sie stellten fest, dass nach der Leberteilresektion die Regeneration der Leber eingeschränkt war, es zu einem verzögerten Wachstum der Leber kam und die Mitose vermindert war. Die Apoptose war bei diesen Mäusen 
höher als bei den Kontroll-Mäusen. Rai et al. (1998) meinen, dass die Apoptose nur in den ersten 24 Stunden höher ist als bei den Kontroll-Mäusen, die Überlebensrate der iNOS knockout-Mäuse war jedoch nicht beeinträchtigt. Die Arbeitsgruppe von Zeini et al. (2005) ging einen Schritt weiter und hemmte zusätzlich zur iNOS das Enzym Cyclooxygenase 2 (COX 2) mit DFU (5,5-Dimethyl-3-(3-Fluorophenyl)-4(4-Methylsulphonyl)phenyl-2(5H)-Furanon). DFU ist ein selektiver COX 2-Inhibitor. Dies führte zu einer signifikant erniedrigten Überlebensrate der Mäuse. In weiteren Experimenten arbeitete die Gruppe mit iNOS-kompetenten Mäusen (Zeini et al. 2005). Dabei inhibitierten sie die iNOS mit einem iNOS-Hemmstoff (1400 W) vor und nach der Leberteilresektion. Die Überlebensrate der Tiere war nicht beeinträchtigt, aber es kam zu einer signifikanten Einschränkung beim Leberwachstum. Daraus schlossen sie, dass die iNOS in der Frühphase der Leberregeneration nach der Leberteilresektion eine schützende Rolle spielt, jedoch keine Auswirkung auf die Überlebensrate der Tiere hat.

\subsection{Einfluss von NO auf die Proliferation der Hepatozyten in vitro}

Bislang zeigte keine Untersuchung einen direkten fördernden Einfluss eines NODonators auf die in vitro Proliferation von Hepatozyten. Garcia-Trevijano et al. (2002) konnten allerdings durch die Gabe eines NO-Inhibitors die mitogene Wirkung von Hepatozytenwachstumsfaktor (HGF) in vitro stark senken, dieser Prozess konnte durch Zugabe des NO-Donators S-Nitroso-N-Acetylpenicillamine wieder aufgehoben werden. Diese Effekte waren jedoch nur bei gleichzeitiger zusätzlicher Gabe von Methionin oder S-Adenosylmethionin (SAM) zum Kulturmedium zu beobachten. Es ist bekannt, dass NO den Spiegel an intrazellulären SAM durch Hemmung der Methioninadenosyltransferase (MAT) senkt (Garcia-Trevijano et al. 2002). Die Autoren folgerten daher, dass NO den Hepatozyten über die Senkung der SAMKonzentration gegenüber HGF sensitisiert.

In einer weiteren umfangreichen Arbeit wurde diese These in vivo und in vitro weiter untersucht (Vázquez-Chantada et al. 2009). Die Autoren postulierten nun eine indirekte Beteiligung der eNOS an der HGF-Signal-Kette (Abb. 12). 


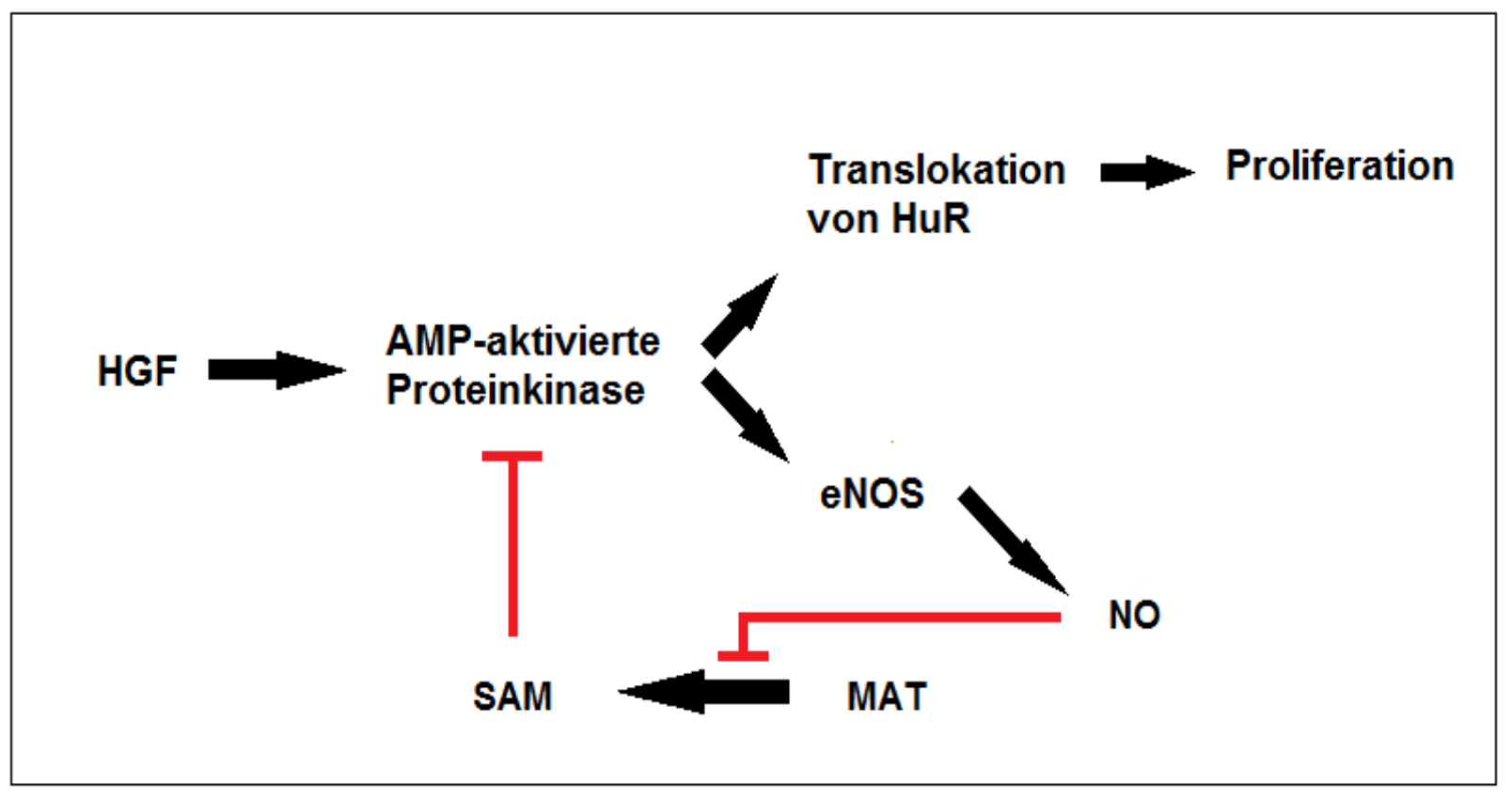

Abb. 12: Hypothetische HGF-Signalkette, Beteiligung der eNOS an der Regulation.

Dabei läuft das Proliferationssignal von HGF über die Aktivierung der AMPaktivierten Kinase zur Translokation des RNA-bindenden Proteins HuR (stabilisiert Cyclin-mRNAs). Die HGF-vermittelte Aktivierung der eNOS führt zur Senkung des SAM-Spiegels durch die Hemmung der MAT. SAM spielt dabei eine zentrale Rolle in der Regulation des Hepatozytenwachstums. Hohe Spiegel an SAM verhindern die Phosphorylierung und Aktivierung der AMP-aktivierten Kinase und der eNOS wahrscheinlich durch eine Aktivierung von Proteinposphatasen. Die MAT bildet SAM. NO senkt den Spiegel von SAM und übt somit einen permissiven Effekt auf die HGFSignalkette aus. Sollte nach einer Leberteilresektion die eNOS-Aktivierung gestört sein, so kommt es zu einer Leberschädigung.

In dieser Dissertation wird gezeigt, dass die iNOS in wachsenden adulten Rattenhepatozyten durch $\mathrm{LiCl}$ induziert werden kann. Lithiumchlorid aktiviert über die Hemmung der Glykogensynthase-Kinase-3 den Wnt-Weg (Du et al. 2006, Aghdam und Barger 2007). Die LiCl-abhängige Proliferation der Hepatozyten wurde jedoch durch zwei iNOS-Inhibitoren, $1400 \mathrm{~W}$ und L-NIL, nicht gehemmt, obwohl die iNOSAktivität zu > 90\% vermindert werden konnte. Also ist die iNOS an der Übermittlung des Wachstumssignals in kultivierten Hepatozyten nicht beteiligt. Auch Ester Wätzig konnte in ihrer Doktorarbeit (2008) keine proliferationsfördernde Wirkung von 
klassischen NO-Donatoren zeigen (Krause et al. 2010). Im Gegenteil, sie beobachtete nach Gabe von NOS-Inhibitoren zwar eine Senkung der NOS-Aktivität um 99\%, aber keine Hemmung des Wachstums.

Die hier vorgestellten Daten widersprechen den publizierten Ergebnissen von GarciaTrevijano et al. (2002) und Vázquez-Chantada et al. (2009). Die Ursache liegt möglicherweise in den sehr unterschiedlichen Kultivierungsbedingungen der Zellen (Tab. 2).

Tabelle 2: Vergleich der Kultursysteme zwischen Vázquez-Chantada et al. (2009) und dem in dieser Arbeit benutzten Kultursystem (Krause et al. 2010)

Kultursysteme Vázquez-Chantada et al. Krause et al. (2010) sowie (2009) diese Arbeit

$\begin{array}{lll}\text { Tierspecies } & \text { Maus } & \text { Ratte } \\ \text { Kultur } & \text { Kurzzeitkultur } & \text { Langzeitkultur } \\ \text { bis 2 Tage } & \text { bis 10 Tage } \\ \text { Medium } & \text { MEM } & \text { Williams E-Medium } \\ & +5 \% \text { FCS } & \text { Insulin } \\ & \text { Kein Zusatz von } & \text { Dexamethason, Hydrocortison } \\ & \text { Hormonen wie } & \text { Transferrin } \\ & \text { Insulin und } & \text { Heparin } \\ & \text { Dexamethason } & \text { EGF und FGFb } \\ & & \text { Mitogene in konditionierten } \\ & & \text { Medien } \\ \text { Zellteilung } & \text { keine } & \text { ja } \\ \text { Zeitdauer der } & 4 \text { Std. } & 10 \text { Tage } \\ \text { Messung } & & \end{array}$

So ist die Maushepatozytenkultur von Garcia-Trevijano und Vázquez-Chantada eine Kurzzeitkultur von maximal $48 \mathrm{~h}$, während der sich die von Anfang der Kultur an konfluenten Zellen nicht mehr teilen, das mitogene Signal (HGF) wird nur über 4 
Stunden verfolgt. Auch fehlt Dexamethason, welches von mehreren Gruppen (Scheving et al. 2007, Block et al. 1996, Bailly-Maitre et al. 2002) als absolut essentiell für die in-vitro-Hepatozyten-Proliferation und -Mitose angesehen wird. In den ersten zwei Tagen klingt die durch die Isolierung der Zellen ausgelöste AkutPhase-Reaktion ab. Erst danach haben die Zellen den Isolierungsstress überwunden. Man kann daher die 2 Kultursysteme nicht gleichsetzen. Bei weiterführenden Untersuchungen muss der SAM-Spiegel einen Verlauf unserer Zellkultivierung gemessen werden. Möglicherweise spielt SAM in unserem Kultursystem keine inhibitorische Rolle, da die Konzentration niedrig sein könnte.

4.3 Wirkung des "NO-Donators" CAS 1609 auf die in-vitro-Proliferation von Hepatozyten

In der Arbeit von Wätzig (2008) wird gezeigt, welche Wirkung CAS 1609 auf das Wachstum der Hepatozyten in vitro hat. Sie fand heraus, dass nur das Furoxan CAS 1609 eine mitogene Wirkung zeigte. Um das Ergebnis zu untermauern, setzte sie das entsprechende Furazan ein, das mit CAS 1609 fast strukturidentisch ist, jedoch kein NO freisetzen kann (siehe Formeln von Furoxan und Furazan auf Seite 6). Dieses Furazan war nicht mitogen aktiv. In dieser Dissertation wird zusätzlich gezeigt, dass in Gegenwart von CAS 1609 die mRNA der iNOS sehr stark vermindert wird (Abb.5).

Zuvor wurde berichtet, dass CAS 1609 das Wachstum von Endothelzellen fördert und die Proliferation der glatten Muskelzellen hemmt (Guo et al. 1995).

Es wurde stets angenommen, dass CAS 1609 ausschließlich ein lang wirkender NODonator ist. Aber in der Literatur gibt es keine eindeutigen Daten, die eine NODonator Eigenschaft unterstützen. Krause et al. (2010) waren überrascht, als sie sahen, dass die aus $100 \mu \mathrm{M}$ CAS 1609 gebildeten Nitrit- und Nitrat-Mengen sehr gering waren (2 bzw $4 \mu \mathrm{M}$ in $24 \mathrm{~h}$ ). Auch zeigten sie, dass CAS 1609 in PBS kein NO freisetzte. Daraus schlossen sie, dass CAS 1609 kein Donator für freies NO ist. Diese Befunde werden auch von anderen Arbeitsgruppen (Boschi et al. 2006, Bohn et al. 1995, Hecker et al. 1995 und Guo et al. 1995) indirekt unterstützt.

Daher stellt sich die Frage, wenn freies NO für die Proliferation der Hepatozyten nicht mitverantwortlich ist, worauf beruht dann die Wirkung von CAS 1609? 
4.4 Direkte Beteiligung von Hämoxygenase-1 und Kohlenmonoxid an der Proliferations-Signalkette

Für die oben gestellte Frage gibt die Arbeit von Schuett et al. (2007) eine Antwort. Diese Arbeitsgruppe beschäftigte sich mit dem Wechselspiel von NO und CO während der Leberregeneration.

Partielle Hepatektomie $(\mathrm{PH})$ führt zur schnellen Produktion von $\mathrm{CO}$ durch die Induktion der Hämoxygenase-1 (HO-1, Yoshida et al. 1984, Schuett et al. 2007). Schuett et al. (2007) fanden heraus, dass partielle Hepatektomie in HO-1 transgenen Tieren die Hepatozytenteilung beschleunigte, vorausgesetzt die Synthese von NO wurde gleichzeitig gehemmt. Ihre Studie zeigte, dass eine Überexpression der HO-1, ohne Gegenregulation durch NO zu Hyperperfusion, erhöhtem mechanischen Stress (shear stress) und erhöhter Leberregeneration führt. Die Autoren postulierten daher eine regulatorische Rolle für NO im Ausbalancieren der physiologisch korrekten COKonzentration durch die NO-abhängige Einstellung des richtigen Blutdruckes zur optimalen Perfusion. Das iNOS/NO System arbeitet so als eine Bremse für unkontrolliertes CO-aktiviertes Zellwachstum.

Es war daher zu untersuchen, ob CAS 1609 in kultivierten Hepatozyten die HO-1 induzierte.

In Abbildung 7 wird gezeigt, dass der HO-1-mRNA-Gehalt in Anwesenheit von CAS 1609 stark anstieg. Dabei spielte der Zeitpunkt der Zugabe von CAS 1609 zur Kultur eine Rolle. Allein durch die Isolierung aus dem Zellverband wurde die HO-1 mRNA transient stark erhöht, daher erhöhte CAS 1609 (Gabe 4 Stunden nach dem Ausplattieren) die mRNA nicht weiter, sondern verminderte den schnellen mRNAAbbau während der anschließenden weiteren 4 Stunden. Wartete man mit der CAS 1609-Zugabe dagegen 48 Stunden, in denen die Zellen den Isolierungsstress überwunden hatten, sah man einen deutlichen Effekt auf den jetzt erniedrigten $\mathrm{HO}-1$ mRNA-Gehalt. CAS 1609 führte zu einem 20-30fachen Anstieg. 
Die Arbeitsgruppe Krause et al. (2010) versetzte die kultivierten Zellen mit dem HO1-Induktor Kobalt-Protoporphyrin (CoPP), um die HO-1-mRNA-Menge zu erhöhen. Dabei wurden eine 500Fache Erhöhung des HO-1-mRNA-Gehalts und eine Verdopplung der Wachstumsgeschwindigkeit erreicht.

Die Zugabe des CO-Donators CORM 2 stimulierte genau wie CAS 1609 das Wachstum der Hepatozyten bei einer optimalen Konzentration von $20 \mu \mathrm{M}$. Eine höhere Konzentration von CORM 2 führte zur Beeinträchtigung der Zellvitalität (Abb. 8). Die Arbeitsgruppe von Sun et al. (2008) untersuchte die Wirkung von CORM 2 auf thermisch verletzte Mäuse in vivo und in vitro. Sie fanden, dass durch CORM 2 freigesetztes $\mathrm{CO}$ die Leberentzündung verminderte und $\mathrm{CO}$ so die Leber vor Schädigung schützte. Dabei wurde gleichzeitig die Expression der HO-1 erhöht, die der iNOS gesenkt und die NO-Konzentration vermindert. Zusätzlich regulierte CORM 2 die Expression von proinflammatorischen Mediatoren, wie TNFa und IL-1ß.

Eine Wachstumsregulation durch $\mathrm{CO}$-freisetzende Substanzen wurde ebenfalls für Endothelzellen (Erhöhung der Proliferation) und glatte Muskelzellen (Erniedrigung der Proliferation) beschrieben (Li Volti et al. 2005, Vadori et al. 2009, Taille et al. 2005, Choi et al. 2008).

Die hier beschriebene Rolle von $\mathrm{CO}$ als mitogener Faktor für die Hepatozytenproliferation wird durch Daten an Hep-G2-Zellen und Keratinozyten unterstützt. HGF führte zu einem transienten Anstieg der HO-1-Induktion in den HepG2-Tumorzellen (Tacchini et al. 2001). In Keratinozyten konnte durch Gabe des NODonators Na-Nitroprussid die HO-1 induziert werden. Ihre erhöhte Aktivität war mit einer erhöhten Zellproliferation gekoppelt; beide Effekte konnten durch ZinnProtoporphyrin, einem Hemmstoff der HO-1, aufgehoben werden (Clark et al. 1997). Auch in wachsenden Rattenhepatozyten war das mitogene Signal von CAS 1609 durch den Hämenzym- Hemmstoffe ODQ (1H-[1,2,4] Oxadiazolo[4,3,-a] quinoxalin-1one) und durch Zink-Protoporphyrin (Hemmstoff der HO-1) zu unterdrücken (Krause et al. 2010), siehe Abbildung 13. 
4.5 Die Bedeutung der HO-1/CO und NOS/NO Signalsysteme für das Wachstum von Rattenhepatozyten in vitro.

In der Abbildung 13 werden die Daten zum durch CAS 1609 regulierten Wachstum zusammengefasst.

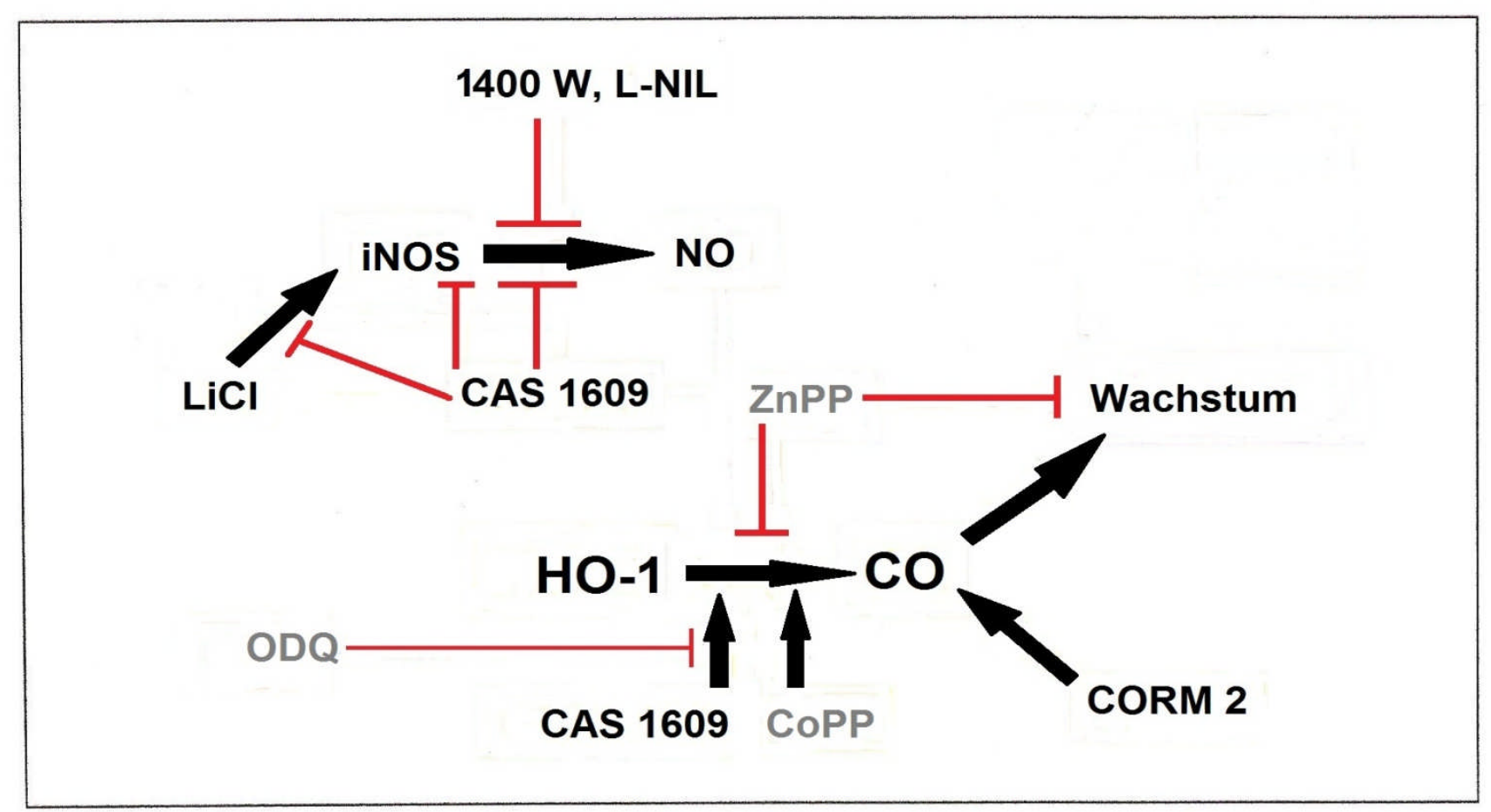

Abb. 13: Die Regulation der NOS/NO und HO-1/CO Signalgeber und des Zellwachstums durch CAS 1609 und Enzymhemmstoffe.

Die Ergebnisse zu den Inhibitoren ODQ, ZnPP und zum Induktor CoPP sind der Arbeit von Krause et al. (2010) entnommen.

CAS 1609 inhibierte als „NO-Donator" die iNOS Expression, NO Freisetzung und verminderte die Wirkung von $\mathrm{LiCl}$ auf die Induktion der iNOS. Gleichzeitig stimulierte CAS 1609 das Hepatozyten-Wachstum konstant und dauerhaft. Die iNOS-Inhibitoren 1400W und L-NIL hatten keinen Einfluss auf das Zellwachstum trotz der Hemmung der iNOS-Aktivität. Daraus wird der Schluss gezogen, dass freies NO und somit die NO-Synthase für das in-vitro-Wachstum der Hepatozyten keine Rolle spielen. Es ist anzunehmen, dass die Hauptaufgabe von CAS 1609 zur Stimulierung des Wachstums in der Induktion der HO-1 und Produktion von $\mathrm{CO}$ liegt. Vermutlich bindet 
CAS 1609 an die Häm-Gruppe von HO-1. Dieser Schluss wird durch die beobachtete mitogene Wirkung der CO-freisetzenden Substanz CORM 2 unterstützt.

ODQ wird als ein spezifischer Inhibitor der löslichen Guanylatcydase (sGC) bezeichnet. Allerdings zeigten Feelisch et al. (1999), dass ODQ kein spezifischer Inhibitor der SGC ist, sondern auch ein nicht selektiver Inhibitor vom Häm-Protein. Sie hemmt SGC, verschiedene NOS-Isoformen und Cytochrom P-450, die an der Bioaktivierung von NO-Donatoren beteiligt sind. ODQ könnte hier das Hämenzym HO-1 hemmen.

Der HO-1-Inhibitor Zink-Protoporphyrin (ZnPP) hemmte das Wachstum der Hepatozyten. Dagegen induzierte Kobalt-Protoporphyrin (CoPP) die HO-1Expression und das Hepatozytenwachstum. 


\section{Zusammenfassung}

Leberregeneration nach Teilhepatektomie führt zu einer erhöhten Bildung von Stickstoffmonoxid (NO) durch NO-Synthasen. NO vermindert die Apoptose und erhöht die Geschwindigkeit der Regeneration. Allerdings konnte bislang kein direkter Effekt von klassischen NO-Donatoren auf die in-vitro-Hepatozytenproliferation gezeigt werden. In-vivo-Daten zeigten, dass bei der Regeneration Kohlenmonoxid (CO) für Hepatozyten mitogen ist. Das Ziel der vorliegenden Arbeit war die Klärung der Fragen, ob 1) ein funktioneller Zusammenhang zwischen der Proliferationsrate kultivierter Hepatozyten und der induzierbaren NO-Synthase (iNOS)-mRNAMenge/NO-Synthase-Aktivität besteht, 2) der mitogen wirkende NO-Donator CAS 1609 einen Einfluss auf die Expression des CO-bildenden Enzyms Hämoxygenase-1 (HO-1) hat und 3) das in-vitro-Wachstum von Hepatozyten durch den CO-Donator CORM 2 gesteigert werden kann.

Als Zellmodell wurden adulte Hepatozyten eingesetzt, die über einen Zeitraum von 10 Tagen serumfrei unter dem Einfluss von konditionierten Medien proliferierten.

1) Durch Lithiumchlorid ( $\mathrm{LiCl}$ ) wurden die Induktion von iNOS-mRNA und die NOSAktivität stark gesteigert. Ab dem 4. Tag kam es unter dem Einfluss von $\mathrm{LiCl}$ zu einer sehr starken Zunahme der iNOS-mRNA, welche ihr Maximum zwischen dem 6.-8. Tag erreichte und gegenüber der Kontrolle ohne $\mathrm{LiCl}$ um das 10-15Fache erhöht war. Die NOS-Aktivität erreichte inr Aktivitätsmaximum am 6. Tag. Das Zellwachstum wurde durch $\mathrm{LiCl}$ ebenfalls stimuliert, der $\mathrm{LiCl}$-abhängige Anstieg war allerdings der iNOS Expression zeitlich vorgezogen. Um herauszufinden, welche Rolle NO in der Zellproliferation spielt, wurde durch Einsatz von spezifischen iNOS-Inhibitoren, wie L-NIL und $1400 \mathrm{~W}$, das Wachstum beobachtet. Obwohl die iNOS-Aktivität in den Zellkulturen über $90 \%$ gehemmt war, war die Proliferation der Hepatozyten nicht beeinträchtigt. Daraus ergibt sich, dass NO für die in-vitro-DNA-Synthese von Hepatozyten nicht benötigt wird.

2) Es konnte gezeigt werden, dass der HO-1-mRNA-Gehalt in Anwesenheit von CAS 1609 sehr stark anstieg. Dabei spielte der Zeitpunkt der Zugabe von CAS 1609 zur Kultur eine wichtige Rolle. Wartete man mit der CAS 1609-Zugabe dagegen 48 
Stunden, bis der Zellisolierungsstress überwunden war, sah man einen deutlichen Effekt auf den sehr niedrigen basalen HO-1-mRNA-Gehalt. CAS 1609 führte zu einem 20-30fachen Anstieg.

3) Als CO-Donator wurde das Tricarbonylchlororuthenium(II)-Dimer (CORM 2) eingesetzt. CORM 2 stimulierte wie CAS 1609 das Hepatozytenwachstum ca. um das Dreifache. Der maximale Effekt wurde mit $20 \mu \mathrm{M}$ CORM 2 erreicht, höhere CORM 2-Konzentrationen führten zur Zellschädigung.

Eine zweite Aufgabe dieser Arbeit bestand darin, adulte Maushepatozyten in vitro zur Proliferation zu bringen. Dazu wurde geschaut, welche Art der Kollagenbeschichtung der Kulturplatte ein Wachstum ermöglichte. Folgende Ergebnisse wurden erhoben: Die Maushepatozyten benötigten im Gegensatz zu Rattenhepatozyten zum Wachstum quervernetztes Kollagen (Glutaraldehyd-quervernetzt). Das WachstumsProtokoll für die Rattenhepatozyten konnte auch für die Maushepatozyten verwendet werden. Im Gegensatz zu der Rattenhepatozytenkultur zeigten die Maushepatozyten ihr Proliferationsmaximum bereits an Tag 4 und stellten ihr Wachstum ab Tag 6 nach Erreichen der Konfluenz ein. Der Zusatz von $\mathrm{LiCl}$ steigerte wie bei Rattenhepatozyten das Wachstum der Maushepatozyten.

\section{Schlussfolgerung}

Die in dieser Arbeit erhobenen Daten zeigen, dass CO eine für Hepatozyten in vitro mitogene Substanz ist und dass die induzierbare Hämoxygenase-1 eine wichtige Rolle in der Wachstums-Signalkaskade einnimmt. Die Daten unterstützen die von Schuett et al. (2007) in vivo nach Teilhepatektomie beobachtete Wachstumsförderung der Hepatozyten durch Überexpression der HO-1. Freies NO und somit die NO-Synthase spielen für das in-vitro-Wachstum der Hepatozyten keine Rolle. Es ist anzunehmen, dass die Hauptaufgabe von CAS 1609 zur Stimulierung des Wachstums in der Induktion der HO-1 und Produktion von CO liegt. Dieser Schluss wird durch die beobachtete mitogene Wirkung der CO-freisetzenden Substanz CORM 2 unterstützt. 


\section{Literaturverzeichnis}

Aghdam SY, Barger SW (2007): Glycogen synthase kinase-3 in neurodegeneration and nueroprotection: lessons from lithium. Curr Alzheimer Res 4(1): 21-31

Anaya-Prado R, Toledo-Pereyra LH, Guo RF, Reuben J, Ward PA, Walsh J (2003): The attenuation of hemorrhage-induced liver injury by exogenous nitric oxide, Larginine, and inhibition of inducible nitric oxide synthase. J Invest Surg 16: 247-261

Bailly-Maitre B, de Sousa G, Zucchini N, Gugenheim J, Boulukos KE, Rahmani R (2002): Spontaneous apoptosis in primary cultures of human and rat hepatocytes: molecular mechanisms and regulation by dexamethasone. Cell Death Differ $\underline{9}$ : 945955

Baranano DE, Rao M, Ferris CD, Snyder SH (2002): Biliverdin reductase: a major physiologic cytoprotectant. Proc Natl Acad Sci USA 99(25): 16093-16098

Block GD, Locker J, Bowen WC, Petersen BE, Katyal S, Strom SC, Riley T, Howard TS, Michalopoulos GK (1996): Population expansion, clonal growth, and specific differentiation patterns in primary cultures of hepatocytes induced by HGF/SF, EGF and TGFa in a chemically defined (HGM) medium.

J Cell Biol 132(6): 1133-1149

Bohlinger I, Leist M, Barsig J, Uhlig S, Tiegs G, Wendel A (1995): Tolerance against tumor necrosis factor alpha (TNF)-induced hepatotoxicity in mice: the role of nitric

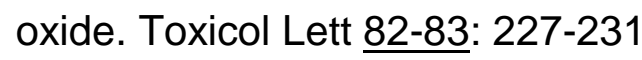

Bohn H., Brendel J., Martorana P.A., Schönafinger K. (1995): Cardiovascular actions of the furoxan CAS 1609, a novel nitric oxide donor, Br J Pharmacol 114: 1605-1612 
Boschi D, Tron GC, Lazzarato L, Chegaev K, Cena C, Di Stilo A, Giorgis M, Bertinaria M, Fruttero R, Gasco A (2006): NO-Donor Phenols: A new class of products endowed with antioxidant and vasodilator properties. J Med Chem 49: 2886-2897

Casado M, Callejas NA, Rodrigo J, Zhao X, Dey SK, Boscá L, Martín-Sanz P (2001): Contribution of cyclooxygenase 2 to liver regeneration after partial hepatectomy. FASEB J 15: 2016-8

Chen T, Zamora R, Zuckerbraun B, Billiar TR (2003): Role of nitric oxide in liver injury. Curr Mol Med $\underline{3}$ : 519-526

Choi HC, Kim HS, Lee KY, Chang KC, Kang YJ (2008): A selective COX-2 inhibitor, inhibits proliferation of IL-1 beta-stimulated vascular smooth muscle cells by induction of HO-1. Biochem Biophys Res Commun 376: 753-757

Clark JE, Green CJ, Motterlini R (1997): Involvement of the heme oxygenase-carbon monoxide pathway in keratinocyte proliferation. Biochem Biophys Res Commun 241(2): 215-220

Clemens MG (1999): Nitric oxide in liver injury. Hepatology 30: 1-5

Du Q, Park KS, Guo Z, He P, Nagashima, Shao L, Sahai R, Geller DA, Hussain SP (2006): Regulation of Human Nitric Oxide Synthase 2 Expression by Wnt ?-Catenin Sinnaling. Cancer Res $\underline{66}$ : 7024-7031

Duval DL, Miller DR, Collier J, Billings RE (1996): Characterization of hepatic nitric oxide synthase: identification as the cytokine-inducible form primarily regulated by oxidants. Mol Pharmacol 50: 277-284 
Esteban FJ, Pedrosa JA, Jimenez A, Fernandez AP, Bentura ML, Martinez-Murillo R, Rodrigo J, Peinado MA (1997): Distribution of neuronal nitric oxide synthase in the rat liver. Neurosci Lett 226: 99-102

Farghali H, Canova N, Gaier N, Lincova D, Kmonickova E, Strestikova P, Masek K (2002): Inhibition of endotoxemia-induced nitric oxide synthase expression by cyclosporin A enhances hepatocyte injury in rats: amelioration by NO donors. Int Immunopharmacol 2: 117-127

Farzaneh-Far R, Moore K (2001): Nitric oxide and the liver. Liver 21: 161-174

Fausto N (2004): Liver regeneration and repair: hepatocytes, progenitor cells, and stem cells. Hepatology $\underline{39}$ : 1477-1487

Feelisch M., Kotsonis P., Siebe J., Clement B., Schmidt H.H.W., (1999): The soluble guanylyl cyclase inhibitor $1 \mathrm{H}-[1,2,4]$ oxadiazolo-[4,3,-a]quinoxalin-1-one is a nonselective heme protein inhibitor of nitric oxide synthase and other cytochrome P450 enzymes involved in nitric oxide donor bioactivation, Mol. Pharmacol. $\underline{56}$ : 243253

Fitzhugh AL, Keefer LK (2000): Diazeniumdiolates: pro- and antioxidant applications of the "NONOates". Free Radic Biol Med 28: 1463-9

Furchgott RF, Jothianandan D (1991): Endothelium-dependent and -independent vasodilation involving cyclic GMP: relaxation induced by nitric oxide, carbon monoxide and light. Blood Vessels 28(1-3): 52-61

Gallucci RM, Simeonova PP, Toriumi W, Luster MI (2000): TNF-alpha regulates transforming growth factor-alpha expression in regenerating murine liver and isolated hepatocytes. J Immunol 164: 872-878 
Garcia-Trevijano E.R, Martinez-Chantar M.L, Latasa M.U, Mato J.M, Avil M.A, (2002): NO sensitizes rat hepatocytes to proliferation by modifying Sadenosylmethionine levels. Gastroenterology 122: 1355-1363

Genaro AM, Hortelano S, Alvarez A, Martínez C, Boscá L (1995): Splenic B lymphocyte programmed cell death is prevented by nitric oxide release through mechanisms involving sustained Bcl-2 levels. J Clin Invest 95: 1884-1990

Giulivi C, Kato K, Cooper CE (2006): Nitric oxide regulation of mitochondrial oxygen consumption I: cellular physiology. Am J Physiol Cell Physiol 291: 1225-1231

Glanemann M, Schirmeier A, Lippert S, Langrehr JM, Neuhaus P, Nussler AK (2005): Cobalt-protoporphyrin induced heme oxygenase overexpression and its impact on liver regeneration. Transplant Proc 37(7): 3223-3225

Guo JP, Panday MM, Consigny PM, Lefer AM (1995): Mechanisms of vascular preservation by a novel NO donor following rat carotid artery intimal injury. Am $\mathrm{J}$ Physiol 269: 1122-1131

Gutteridge JM (1995): Lipid peroxidation and antioxidants as biomarkers of tissue damage. Clin Chem 41(12 Pt 2): 1819-1828

Harbrecht BG, Billiar TR (1995): The role of nitric oxide in Kupffer cell-hepatocyte interactions. Shock $\underline{3}$ : 79-87

Hecker M, Vorhoff W, Bara AT, Mordvintcev PI, Busse R (1995): Characterization of furoxans as a new class of tolerance-resistant nitrovasodilatators. NaunynSchmiederbergs Arch Pharmacol 351: 426-432 
Isobe M, Katsuramaki T, Hirata K, Kimura H, Nagayama M, Matsuno T (1999): Beneficial effects of inducible nitric oxide synthase inhibitor on reperfusion injury in the pig liver. Transplantation $\underline{68}: 803-813$

Joshi MS, Ponthier JL, Lancaster JR (1999): Cellular antioxidant and pro-oxidant actions of nitric oxide. Free Radic Biol Med 27: 1357-1366

Kelm M (1999): Nitric oxide metabolism and breakdown. Biochem Biophys-Acta 1411: 273-289

Kharitonov VG, Sundquist AR, Sharma VS (1995): Kinetics of nitrosation of thiols by nitric oxide in the presence of oxygen. J Biol Chem 270(47): 28158-28164

Kim PK, Zamora R, Petrosko P, Billiar TR (2001): The regulatory role of nitric oxide in apoptosis. Int Immunopharmacol 1: 1421-1441

Kim PK, Zuckerbraun BS, Otterbein LE, Vodovotz Y, Billiar TR (2004): Til cell death do us part: nitric oxide and mechanisms of hepatotoxicity. Biol Chem 385: 11-15

Kim YM, Bergonia H, Lancaster JR Jr (1995): Nitrogen oxide-induced autoprotection in isolated rat hepatocytes. FEBS Lett 374: 228-232

Kitade H, Saktiani K, Inoue K, Masu Y, Kawada N, Hiramatsu Y, KamiyamaY, Okumura T, Ito $S$ (1996): Interleukin 1 B markedly stimulates Nitric Oxid formation in the Absence of ohter Cytokins or Lipopolysaccharide in primary cultured rat Hepatocytes but Not in Kupffer Cells. Hepatology 23(4): 797-802 
Koenig S., Krause P., Drabent B., Schaeffner I., Christ B., Schwartz P., UnthanFechner K., Probst I., (2006): The expression of mesenchymal, neural and haematopoietic stem cell markers in adult hepatocytes proliferating in vitro. $\mathrm{J}$ Hepatol 44: $1115-1124$

Krause P, Wätzig E, Acil H, König S, Unthan-Fechner, Tsikas D, Prost I, (2010): Role of carbon monoxide and nitric oxide in adult rat hepatocytes proliferating in vitro: Effects of CAS 1609. Nitric Oxide 23(3): 220-226

Laskin DL, Pilaro AM, Ji S (1986): Potential role of activated macrophages in acetaminophen hepatotoxicity. II. Mechanism of macrophage accumulation and activation. Toxicol Appl Pharmacol 86: 216-226

Lavon I, Goldberg I, Amit S, Landsman L, Jung S, Tsuberi BZ, Barshack I, Kopolovic J, Galun E, Bujard H, Ben-Neriah Y (2000): High susceptibility to bacterial infection, but no liver dysfunction, in mice compromised for hepatocyte NF-kappaB activation. Nat Med $\underline{6}:$ 573-577

Li X, Clark JD (2000): Heme oxygenase type 2 plays a role in formalin-induced nociception. Pain $\underline{86(1-2)}:$ 75-80

Lindenblatt N, Bordel R, Schareck W, Menger MD, Vollmar B (2004): Vascular heme oxygenase-1 induction suppresses microvascular thrombus formation in vivo. Arterioscler Thromb Vasc Biol 24(3): 601-606

Livak KJ, Schmittgen TD (2001): Analysis of relative gene expression data using realtime quantitative PCR and the 2 (-Delta Delta C (T)) Method. Methods 25: 402-408 
Li Volti G, Sacerdoti D, Sangras B, Vanella A, Mesentsev A, Scapagnini G, Falck JR, Abraham NG (2005): Carbon monoxide signaling in promoting angiogenesis in human microvessel endothelial cells. Antioxid Redox Signal 7: 704-710

Maines MD (1988): Heme oxygenase: function, multiplicity, regulatory mechanisms, and clinical applications. FASEB J 2(10): 2557-2568

Maines MD (1997): The heme oxygenase system: a regulator of second messenger gases. Annu Rev Pharmacol Toxicol 37: 517-54

Maines MD, Trakshel GM, Kutty RK (1986): Characterization of two constitutive forms of rat liver microsomal heme oxygenase. J Biol Chem 261(1): 411-419

McCoubrey WK Jr, Huang TJ, Maines MD (1997): Isolation and characterization of a cDNA from the rat brain that encodes hemoprotein heme oxygenase-3. Eur $\mathrm{J}$ Biochem 247(3): 725-732

McNaughton L, Puttagunta L, Martinez-Cuesta MA, Kneteman N, Mayers I, Mogbel R, Hamid Q, Radomski MW (2002): Distribution of nitric oxide synthase in normal and cirrhotic human livere. Proc Natl Acad Sci USA 99: 17161-17166

Mempel TR, Scimone ML, Mora JR, Andrian UH (2004): In vivo imaging of leukocyte trafficking in blood vessels and tissues. Curr Opin Immunol 16(4): 406-417

Meredith MJ (1988): Rat hepatocytes prepared without collagenase: prolonged retention of differentiated characteristics in culture. Cell Biol Toxicol 4(4): 405-425

Michalopoulos GK, DeFrances MC (1997): Liver regeneration. Science 276: 60-66 
Morse D, Choi AM. (2002): Heme oxygenase-1: the "emerging molecule" has arrived. Am J Respir Cell Mol Biol 27(1): 8-16

Nüssler AK, Geller DA, Sweetland MA, Di Silvio M, Billiar TR, Madariaga JB, Simmons RL, Lancaster JR (1993): Induction of nitric oxide synthesis and its reactions in cultured human and rat hepatocytes stimulated with cytokines plus LPS. Biochem Biophys Res Commun 194: 826-835

Obolenskaya M, Schulze-Specking A, Plaumann B, Frenzer K, Freudenberg N, Decker K (1994): Nitric oxide production by cells isolated from regenerating rat liver. Biochem Biophys Res Commun 204: 1305-1311

Otterbein LE, Choi AM (2000): Heme oxygenase: colors of defense against cellular stress. Am J Physiol Lung Cell Mol Physiol 279(6): 1029-1037

Penney DG (1988): Hemodynamic response to carbon monoxide. Environ Health Perspect $\underline{77}$ : 121-130

Rai RM, Lee FY, Rosen A, Yang SQ, Lin HZ, Koteish A, Liew FY, Zaragoza C, Lowenstein C, Diehl AM (1998): Impaired liver regeneration in inducible nitric oxide synthase-deficient mice. Proc Natl Acad Sci USA 95: 13829-13834

Ronco MT, Alvarez M de L, Monti JA, Carrillo MC, Pisani GB, Lugano MC, Carnovale CE (2004): Role of nitric oxide increase on induced programmed cell death during early stages of rat liver regeneration. Biochem Biophys Acta 1690: 70-76

Rosenfeld ME, Prichard L, Shiojiri N, Fausto N (2000): Prevention of hepatic apoptosis and embryonic lethality in RelA/TNFR-1 double knockout mice. Am J Pathol 156: 997-1007 
Scheving LA, Buchanan R, Krause MA, Zhang X, Stevenson MC, Russell WE (2007): Dexamethasone modulates ErbB tyrosine kinase expression and signaling through multiple and redundant mechanisms in cultured rat hepatocytes. Am $\mathrm{J}$ Physiol Gastrointest Liver Physiol 293: 552-559.

Schuett H, Eipel C, Maletzki C, Menger MD, Vollmar B (2007): NO counterbalances HO-1 overexpression-induced acceleration of hepatocyte proliferation in mice. Lab Invest 87: 602-612

So HS, Jung BH, Song HS, Myung, Kim S, Park JS, Chae KM, Lee JH, Chung SY, Chae HJ, Kim HR, Park R (2001): Nitric oxide prevents the IFN-gamma/LPS-induced hepatotoxicity in a protein kinase G-independent manner. Immunopharmacol Immunotoxicol 23: 321-334

Srivastava RC, Dwivedi RS, Kaur G, Srivastava R (1982): Haem and drugmetabolizing enzymes in regenerating rat liver. $\mathrm{Br} \mathrm{J}$ Exp Pathol 63: 1-4

Sun BW, Sun Y, Sun ZW, Chen X (2008): CO liberated from CORM 2 modulates the inflammatory response in the liver of thermally injures mice. World $J$ Gastroenterol 14(4): 547-553

Suzuki H, Menegazzi M, Carcereri de Prati A, Mariotto S, Armato U (1995): Nitric oxide in the liver: physiopathological roles. Adv Neuroimmunol $\underline{5}$ : 379-410 
Tacchini L, Danis P, Matteucci E, Desiderio MA (2001): Hepatocyte growth factor signalling stimulates hypoxia inducible factor-1 (HIF-1) activity in HepG2 hepatoma cells. Carcinogenesis 22(9): 1363-1371

Taillé C, El-Benna J, Lanone S, Boczkowski J, Motterlini R (2005): Mitochondrial respiratory chain and $\mathrm{NAD}(\mathrm{P}) \mathrm{H}$ oxidase are targets for the antiproliferative effect of carbon monoxide in human airway smooth muscle. J Biol Chem 280: 25350-25360

Tenhunen R, Marver HS, Schmid R. (1968): The enzymatic conversion of heme to bilirubin by microsomal heme oxygenase. Proc Natl Acad Sci 61(2): 748-755

Tenhunen R, Marver HS, Schmid R (1969): Microsomal heme oxygenase. Characterization of the enzyme. J Biol Chem 244(23): 6388-6394

Thews O, Kelleher DK, Vaupel P (2000): Disparate responses of tumour vessels to angiotensin II: tumour volume-dependent effects on perfusion and oxygenation. $\mathrm{Br} \mathrm{J}$ Cancer 83(2): 225-231

Tsikas D (2004): Assessment of nitric oxide biosynthesis and peroxynitrite formation within the central nervous system by measuring L-citrulline in the cerebrospinal fluid? J Chromatogr B Analyt Technol Biomed Life Sci 813(1-2): 359-61

Tsikas D, Sandmann J, Savva A, Luessen P, Böger RH, Gutzki FM, Mayer B, Frölich JC (2000): Assessment of nitric oxide synthase activity in vitro and in vivo by gay chromotrography-mass spectrometry. J Chromotogr B Biomed Sci Appl 742(1): $143-153$ 
Vadori M, Seveso M, Besenzon F, Bosio E, Tognato E, Fante F, Boldrin M, Gavasso S, Ravarotto L, Mann BE, Simioni P, Ancona E, Motterlini R, Cozzi E (2009): In vitro and in vivo effects of the carbon monoxide-releasing molecule, CORM-3, in the xenogeneic pig-to-primate context. Xenotransplantation 16(2): 99-114

Vázquez-Chantada M, Ariz U, Varela-Rey M, Embade N, Martínez-Lopez N, Fernández-Ramos D, Gómez-Santos L, Lams S, C.Lu S, Martínez-Chantar M. Luz, Mato J.M, (2009): Evidence for LKB1/AMP-activated protein kinase/endothelial nitric oxide synthase cascade regulated by hepatocyte growth factor, S-

adenosylmethionine, and nitric oxide in hepatocyte proliferation. Hepatology $\underline{49}$ : 608617

Wagner M, Cadetg P, Ruf R, Mazzucchelli L, Ferrari P, Redaelli CA (2003): Heme oxygenase-1 attenuates ischemia/reperfusion-induced apoptosis and improves survival in rat renal allografts. Kidney Int $\underline{63(4)}$ : 1564-1573

Wätzig E: Die Bedeutung von Stickoxid und der induzierbaren NO-Synthase für den Proliferationsprozess adulter primärkultivierter Rattenhepatozyten. Med. Diss. Göttingen 2008

Wei CL, Khoo HE, Lee KH, Hon WM (2002): Differential expression and localization of nitric oxide synthases in cirrhotic livers of bile duct-ligated rats. Nitric Oxide $\underline{7}$ : 91 102

Yoshida T, Arakaki M, Kumakawa J, Kuroiwa Y (1984): An induction of heme oxygenase and its possible relation to the decrease of cytochrome P-450 content during liver regeneration. J Pharmacobiodyn $\underline{7}$ : 112-119 
Zamora R, Alarcon L, Vodovotz Y, Betten B, Kim PK, Gibson KF, Billiar TR (2001): Nitric oxide suppresses the expression of Bcl-2 binding protein BNIP3 in hepatocytes. J Biol Chem 14: 46887-46895

Zeini M, Hortelano S, Través PG, Gómez-Valadés AG, Pujol A, Perales JC, Bartrons $R$, Boscá $L$ (2005): Assessment of a dual regulatory role for NO in liver regeneration after partial hepatectomy: protection against apoptosis and retardation of hepatocyte proliferation. FASEB J 19: 995-997

Zima T, Fialova L, Mestek O, Janebova M, Crkovska J, Malbohan I, Stipek S, Mikulikova L, Popov P (2001): Oxidative stress, metabolism of ethanol and alcoholrelated diseases. J Biomed Sci $\underline{8}:$ 59-70 